\title{
Leyendas marianas e imágenes milagrosas en la historia de la religiosidad popular de Andalucía (siglos XII-XVII)
}

\author{
Marian Legends and Miraculous Images in the History of Popular \\ Religiosity in Andalusia (12-17th Centuries)
}

\author{
Andrea Mariana NAVARRO \\ Universidad Nacional de Tucumán \\ República Argentina \\ andrea1816@yahoo.com
}

\section{RESUMEN}

El interés por la religiosidad popular y sus expresiones: creencias, prácticas y discursos se ha venido multiplicando desde hace años en diversos estudios, en este caso el artículo intenta presentar algunas características sobre el culto de las imágenes marianas en la sociedad medieval andaluza con el objetivo de demostrar de qué forma, a través del repertorio de leyendas sobre milagros, la Iglesia encaró asuntos centrales como la valoración, uso y significación de las imágenes religiosas, valiéndose de recursos hagiográficos y apoyándose en principios teológicos para justificar la sacralidad de las mismas, para alentar devociones y enfrentar controversias.

Palabras clave: Leyendas marianas, Imágenes, Milagros, Religiosidad popular, Andalucía, Castilla, Siglos XII-XVII.

\begin{abstract}
An interest in popular religiosity and its expressions - beliefs, practices and discourses - has grown over the years in diverse studies. This article attempts to present certain characteristics of the cult of Marian images in medieval Andalusian society, with the goal of demonstrating how the Church used the repertory of legends about miracles to confront such central issues as the assessment, use and meaning of religious images, utilizing hagiographic resources and drawing support from theological principles to justify their sacrality, encourage devotions and face controversies.
\end{abstract}

Key words: Marian legends, Images, Miracles, Popular Religiosity, Andalusia, Castile, $12 \mathrm{t}^{\mathrm{h}}-17^{\text {th }}$ Centuries.

Sumario: Introducción. 1. Los problemas de valoración, uso y significación de las imágenes religiosas. 1.1 Cuestiones teológicas centrales en el culto a las imágenes (s. IV-VII). 1.2. Controversias doctrinales: iconodulia e iconoclastia (s. VIII-IX). 1.3 El proceso sacralizador de las imágenes de culto (s. XI-XV). 1.4. Reforma Protestante y Contrarreforma: reacción y defensa del culto a las imágenes (s. XVI). 2. Imágenes y devoción mariana. 2.1. Imágenes marianas milagrosas en la Reconquista de Andalucía. 2.2. Imágenes marianas milagrosas y protectoras de ciudades y comarcas. 2.3. Translatio e Inventio de imágenes milagrosas. 2.4. Apariciones de la Virgen y sus imágenes. 3. Consideraciones finales. 


\section{INTRODUCCIÓN}

En la religión cristiana las imágenes de culto desempeñaron un papel primordial a la hora de producir la experiencia de lo sagrado, así por ejemplo desde las postrimerías de la Antigüedad hasta la Temprana Edad Moderna, las tallas, esculturas y pinturas colocadas en las iglesias ocuparon un lugar central entre las expresiones de la religiosidad, favorecieron el desarrollo de devociones y la emergencia de santuarios que, convertidos en metas de romerías y peregrinaciones, fueron configurando una geografía de la fe y la piedad. ${ }^{1}$ No obstante, a lo largo de varios siglos se desarrollaron controversias teológicas en torno al uso y veneración de las imágenes, en ellas sus defensores y detractores fueron elaborando doctrinas que marcarían las tradiciones religiosas de la sociedad cristiana. En ese contexto tuvieron su origen una serie de leyendas de culto y milagros de antiguas imágenes marianas que analizaremos en este trabajo. Nos centraremos en la región andaluza con el objeto de mostrar las creencias y prácticas religiosas medievales que reflejaron el poder atribuido por los fieles y la Iglesia Católica hispánica a las imágenes sagradas, para ello nos basaremos en fuentes historiográficas, en los comentarios de cronistas e historiadores -en su mayoría del estamento eclesiástico- que recogieron leyendas transmitidas por una tradición constante.

${ }^{1}$ Con este artículo agradezco y destaco la labor y trayectoria desarrollada por el Dr. Miguel Angel Ladero Quesada, sus valiosos aportes a los estudios de Historia Medieval, su dedicación en la dirección y formación de generaciones de discípulos (entre los cuales me encuentro) así como expreso mi reconocimiento a su desempeño como director de esta publicación del Departamento de Historia Medieval de la Universidad Complutense de Madrid, que ha sido un espacio importante de difusión y actualización de la producción científica en el área. La Historia de las Imágenes ha permitido indagar el contenido intelectual, la filosofía o la teología que llevaban implícitas, su significado intrínseco, los principios y valores subyacentes que revelaban el carácter de una época, una sociedad, unas creencias religiosas, la cultura. Véase PANOFSKY, E: Estudios sobre iconología, Alianza, Madrid, 1972; Fritz, S: La vida de las imágenes, Madrid, 1988; FreedBerg, D: El poder de las imágenes: estudio sobre la historia y la teoría de la respuesta, Cátedra, Madrid, 1992; BASCHET, J. y Sснміт, J-C (eds): L'images. Fonctions et usages des images dans l'Occident medieval, Cahiers Le Leopard du or 5, París, 1996; Gombrich, E. H: Imágenes simbólicas, Alianza, Madrid, 2001 y Los usos de las imágenes: estudios sobre la función social del arte y la comunicación visual, Editorial Debate, Barcelona, 2003. En esas coordenadas, en las que las imágenes proporcionan a la Historia de la Cultura un testimonio útil, se inscriben también los sugerentes trabajos del alemán Hans Belting, especialista en arte medieval y renacentista, que ha venido situando el estudio de las imágenes en el centro de interés de historiadores y antropólogos. Para este autor, la Edad Media representó esencialmente la "era de las imágenes de culto" por haber sido éstas objetos privilegiados de las prácticas religiosas, acreedoras de veneración en el cristianismo y porque el uso que se hizo de ellas en la cultura medieval las diferenció y excluyó sustancialmente del "arte" surgido a partir de la crisis de la "vieja imagen" y de una nueva valoración en el Renacimiento, en los albores de la Edad Moderna. En Imagen y culto. Una historia de la imagen anterior a la era del arte, Akal, 2009 trata de las imágenes y no del "arte" -término que no empezó a utilizarse en Occidente hasta el Renacimiento, cuando la función estética de las imágenes prevaleció sobre otros usos- y de la "crisis de la imagen" a partir de la Reforma Protestante. 


\section{LOS PROBLEMAS DE VALORACIÓN, USO Y SIGNIFICACIÓN DE LAS IMÁGENES RELIGIOSAS}

\subsection{CUESTIONES TEOLÓGICAS CENTRALES EN EL CULTO A LAS IMÁGENES (S. IV-VII)}

Desde épocas muy tempranas existieron críticas sobre el uso de los símbolos materiales de la fe. La diversidad de formas y contenidos que adquirieron las imágenes religiosas plantearon en los círculos eruditos interrogantes acerca de la continuidad del culto de las imágenes del paganismo en el cristianismo, sobre la veneración de la imagen o lo que ella representaba, sobre la posible "presencia de lo divino", en otras palabras, sobre lo que podía haber de celestial en ellas cuando estaban hechas por manos humanas. ${ }^{2}$

Algunas de estas cuestiones se habían reflejado en las prohibiciones de las imágenes cultuales establecidas en el Antiguo Testamento (Éxodo 20: 4-5, Éxodo 32, Deuteronomio 5:8-9, Isaías 44:9-20, Jeremías 10:1-16, Reyes 12:26-33) concepción que mantuvieron esencialmente los primeros teólogos de los siglos II y III d. C. Hacia los años 305-306 las mismas preocupaciones se plasmaron en el concilio de Elvira (Liberris, Granada) donde los obispos hispanos trataron de prohibir la utilización de pinturas en las iglesias y elaboraron leyes severas contra los cristianos que recaían en la idolatría y la herejía (canon 36). Asimismo, en las epístolas que el papa Gregorio Magno envió entre los siglos VI y VII al obispo Sereno de Marsella -que había ordenado destruir las pinturas y esculturas de su diócesis por temor a caer en la idolatríapueden leerse reflexiones sobre la utilidad y límites en el uso de las imágenes. En ellas afirmó que no debían ser adoradas como lo hacían los paganos con sus ídolos pero sí veneradas, lo que significaba darles un honor especial pues cumplían importantes funciones: conducían al recuerdo y a la memoria de la historia sagrada de la salvación, de los ejemplos de vida virtuosa e instruían a los iletrados que no tenían como los clérigos acceso a las Sagradas Escrituras (Ep. 11,13; Ep. 7,2:3; Ep. 9,4:9). Por consiguiente, tenían tanto valor como los textos por su eficacia pedagógica, ya que las imágenes podían actuar a modo de refuerzo tanto del mensaje escrito como del oral, de los sermones y las predicaciones. ${ }^{3}$

${ }^{2}$ En la Antigüedad los paganos pensaban que sus estatuas sagradas tenían poderes puesto que estaban imbuidas de los espíritus de los dioses a los que representaban y podían ser vivificadas a través de ceremonias mágicas efectuadas por los sacerdotes. La creencia de que se "fabricaban en el cielo pero se hacían en la tierra" -cuestionada por San Agustín en La Ciudad de Dios-, se convirtió en motivo de disputa con los cristianos que no admitían que en la materia inanimada pudiera haber algún vestigio de la divinidad y afirmaban que los supuestos poderes sólo podían ser obra de demonios, pensamiento que se vio reflejado en los textos e ilustraciones de las Biblias europeas y de los legendarios de los siglos XII, XIII y XIV. Véase GARCíA AvILÉs, A: "Falsas estatuas: ídolos mágicos y dioses artificiales en el siglo XIII", en García Avilés, A. (Ed): Magic in Medieval Spain (La corónica: A Journal of Medieval Hispanic Language, Literatura and Cultural Studies), Nueva York, 2007, pp. 71-96

3 Viciano i Vives, A: "Fundamentos teológicos de la iconografía cristiana: una perspectiva histórica", II Congreso Internacional de cofradias y hermandades, Universidad Católica San Antonio (2008), pp. 81-103. 


\subsection{CONTROVERSIAS DOCTRINALES: ICONODULIA E ICONOCLASTIA (S. VIII-IX)}

La problemática sobre la diferencia entre la imagen y lo representado, entre adoración (debida exclusivamente a Dios) y veneración (rendida a una imagen) se hizo patente en las Querellas iconoclastas de los siglos VIII y IX. El enfrentamiento entre la Iglesia del Occidente latino y del Oriente bizantino no quedó zanjado hasta el IV concilio de Constantinopla del año 843 en que la emperatriz Teodora institucionalizó las imágenes sobre tablas o planos, reconociéndolas definitivamente para uso litúrgico y como parte integrante del culto ortodoxo.

Como se sabe, en Oriente la reacción contra determinados usos de los íconos y contra ciertas desviaciones en los comportamientos de los fieles (postraciones, besos, empleo de inciensos y ropas para vestirlos, el apadrinamiento de niños) derivó en la prohibición de imágenes tanto públicas como privadas, en decretos de excomunión y en la lucha contra los monjes que habían hecho un culto de los íconos convirtiéndolos en soporte del poder monástico, de su riqueza e influencia. ${ }^{4} \mathrm{El}$ sínodo de la Iglesia romana convocado por el papa Gregorio III se opuso a la destrucción de las imágenes decretada en el año 726 por el emperador León III excomulgando a los adversarios de los iconódulos. Sin embargo, tales medidas no consiguieron impedir la implantación de la doctrina por su hijo, Constantino V Coprónico, que en el concilio de Hiereia, en el año 754, defendió la imposibilidad de representar a Cristo por su naturaleza divina y tampoco cabía limitarse a hacerlo en su naturaleza humana ya que su única imagen se hallaba en la Eucaristía. ${ }^{5}$ En ese contexto, la defensa del culto a las imágenes se llevó a cabo en el II concilio de Nicea del año 787 que anuló los decretos imperiales adoptando disposiciones que tuvieron como base una vieja fórmula de Basilio de Cesarea postulada por el monje y teólogo Juan Damasceno ${ }^{6}$, quien afirmó la distinción entre el culto cristiano y la idolatría condenada por las Sagradas Escrituras y sostuvo la validez de las representaciones fundadas en la Encarnación de Cristo así como de la veneración que se dirigía no a la materia sino al ser representado. ${ }^{7}$

\subsection{EL PROCESO SACRALIZADOR DE LAS IMÁGENES DE CULTO (S. XI-XV)}

Erradicar cualquier semejanza con los ídolos paganos que aún subyacía en las creencias de la sociedad medieval suponía desmontar toda acusación y duda que pesaba sobre las imágenes de culto. Los íconos - planos- o imágenes corporeizadas -de bulto o de tres dimensiones- tuvieron en la cultura occidental cristiana su época de apogeo

\footnotetext{
${ }^{4}$ Grabar, A: La iconoclastia bizantina. Dossier arqueológico. Madrid, 1984 (2ºd)

${ }^{5}$ García Villoslada, R. (Dir): Historia de la Iglesia Católica III. La Edad Nueva: La Iglesia en la época del Renacimiento y la Reforma Católica (1303-1648), BAC, Madrid, 1976.

${ }^{6}$ Véase Tres dicursos sobre los iconoclastas y Exposición de la fe católica.

7 Belting, H: "Semejanza y presencia: la introducción a las imágenes antes de la era del arte", Revista de Historia del Arte, № 5, vol. 3 (2003); Schmitт, J-C: "Imágenes", en Le Goff, J. y Schmitt, J-C (eds), Diccionario razonado del Occidente Medieval, Akal, 2003 y García Avilés, A: "Transitus. Actitudes hacia la sacralidad de las imágenes en el Occidente Medieval”, en Boto, J. (ed): Imágenes medievales de culto, Murcia, 2010 .
} 
en los siglos del arte románico y del gótico, cuando la Iglesia validó la idea de que podían estar infundidas de un poder, energeia o dynamis, que del griego se tradujo al latín como virtus sancta. De esta forma se oponía fehacientemente a la magia de los ídolos, la virtus procedía del prototipo sagrado -y no de un objeto inanimado- y era capaz de realizar milagros. El IV concilio de Letrán de 1215 y la doctrina de la transustanciación que pusieron énfasis en la humanidad de Cristo y en la materialidad del ritual litúrgico allanaron el camino y beneficiaron a la teoría de las imágenes. La literatura hagiográfica y la historiografía dan cuenta de cómo se potenció el culto a las imágenes haciéndolas partícipes de la santidad, ya no sólo como una necesidad imperiosa de satisfacer la fe de los fieles que no sabían $l_{\text {eer }}^{8}$, sino para popularizar devociones cuestionadas por corrientes heréticas como la de los cátaros. Si hasta entonces habían sido las reliquias y las imágenes-relicario objetos de especial veneración, ahora se estaba configurando una religiosidad basada en el culto a las "imágenes virtuosas".

Por otra parte, para responder a las críticas de idolatría, los religiosos distinguieron tres formas de relación con lo sagrado: latría, dulía e hiperdulía. La primera se debía sólo a Dios en cuanto "criador de todo según la excelencia grande e incomprehensible que tiene sobre todas las criaturas", así la palabra aludía al servicio y reverencia llena de temor y encogimiento; la segunda significaba una manera de culto y reverencia que la Iglesia llama "menor" y se da a los santos; la tercera era propia de quien tiene la mayor cercanía con Dios, es inferior a El pero superior a todas las criaturas, por ello está entre la latría y la dulía y debe darse sólo a la Virgen.

\subsection{REFORMA PROTESTANTE Y CONTRARREFORMA: REACCIÓN Y DEFENSA DEL CULTO A LAS IMÁGENES (S. XVI)}

En el siglo XVI la Reforma Protestante volvió a orientar estos planteos suscitados a lo largo de la Edad Media en torno a la pureza de la fe y a la verdadera espiritualidad que parecía amenazada por el materialismo de las imágenes. Su crítica -que se articulaba bien con la búsqueda de renovación de la institución eclesiástica- fue un motivo por el cual los reformadores se convirtieron en sus principales enemigos. Para éstos, la pureza de la doctrina se apoyaba en la literalidad del texto, la palabra de Dios en la Biblia, considerada el único espejo en el que la fe podía ver y contemplar a Dios invisible y que podía llegar a todos gracias a la imprenta y a la lengua vernácula. Por otra parte, la nueva justificación del cristiano sólo por su fe hacía innecesarias las donaciones piadosas de imágenes o para imágenes y reliquias, viniéndose abajo el sistema de exvotos. ${ }^{9}$

Entre los partidarios luteranos y calvinistas, estos últimos representaron el ala más rigorista, no sólo porque no toleraron ninguna limitación en el dualismo entre espíritu y materia, sino porque atacaron la veneración y la mera producción de la imagen que

\footnotetext{
${ }^{8}$ Véase la justificación al culto a las imágenes por Santo Tomás de Aquino en la Suma Teológica, apoyada en la Carta a los Romanos 1,14. Se refirió a una triple utilidad: como instrumento de información, para memoria de los misterios de la salvación y como estímulo a la devoción.

${ }^{9}$ Martínez-Burgos García, P: Idolos e imágenes. La controversia del arte religioso en el siglo XVI español. Problema de los valores, usos y significación de la imagen religiosa, Universidad de Valladolid, 1990.
} 
representaba. ${ }^{10}$ Asimismo, como predicador de una nueva piedad Erasmo de Rótterdam valoró y separó lo espiritual de lo material, advirtiendo los peligros en los que incurrían los fieles que se quedaban sólo con lo visible. ${ }^{11}$ De este modo, la Reforma puso a prueba las prácticas devocionales del cristianismo y forzó una reconsideración que afectó no sólo al fondo teológico de las mismas, sino a las formas en que se realizaban el culto y los rituales.

La cultura católica, en cambio, acentuó los rasgos criticados por el protestantismo. En diciembre de 1563, la sesión XXV del concilio de Trento aprobó el decreto De invocatione, veneratione et reliquiis sanctorum et sacres imaginibus que estableció como doctrina católica la adoración de los santos frente a la acusación de los protestantes de idolatría, declarando que se debían tener y conservar, principalmente en los templos, las imágenes de Cristo, la Virgen Madre de Dios y de otros santos, y que se les debía dar la correspondiente veneración porque el honor a las imágenes se refería a los originales representados en ellas. La Contrarreforma Católica reivindicó la eficacia y el poder de las imágenes convirtiéndolas en instrumentos fundamentales de las prácticas religiosas y las devociones, situándolas en igual rango que las Sagradas Escrituras y las reliquias, de las que se creía podían heredar como éstas la presencia de los representados y las características funcionales.

\section{IMÁGENES Y DEVOCIÓN MARIANA}

De acuerdo con la tradición cristiana, la tumba de María fue encontrada vacía porque su cuerpo fue asunto a los cielos, precisamente esa ausencia y las escasas reliquias por contacto (brandea) conocidas (gotas de leche, zapato, cabellos y manto) favorecieron la fe en las apariciones milagrosas y constituyó un motivo y un estímulo para que su imagen (íconos, tallas y esculturas) se convirtiera en elemento central como garantía de culto, asegurando su veneración universal al no estar concentrada su "presencia" en pocos y exclusivos lugares de la geografía de la santidad cristiana. Sobre algunas de sus imágenes de origen misterioso que adquirieron capacidad de obrar milagros se elaboraron leyendas en las que se les reconocía un comportamiento similar al de las reliquias, al considerarlas también recipientes de la más alta presencia real de la Virgen. Así por ejemplo, de la misma manera que se les atribuyó carácter sagrado a los retratos pintados de María por el evangelista San Lucas -ante quien se cree habría posado la Virgen en vida- y a las imágenes escultóricas realizadas por San Nicodemo, otras imágenes religiosas adquirieron gran influjo en las mentalidades y en las prácticas colectivas pues no se consideraron meros objetos de contemplación sino de culto, favorecidas por la fe popular, la leyenda y la milagrería. ${ }^{12}$

${ }^{10}$ Battaillon, M: Erasmo y España, México, 1993.

${ }^{11}$ Las obras, difundidas en España después de 1520, que contienen su pensamiento acerca de las imágenes y las críticas a las prácticas religiosas son Manual del caballero cristiano; El elogio de la locura; Coloquios y Modus orandi Deum.

12 A través de la hagiografía conocemos la mayor parte de las colecciones de relatos sobre milagros y leyendas marianas de la tradición religiosa europea, algunas fueron recogidas en el siglo VII en el Libri Miraculorum por Gregorio de Tours; en las obras de San Ildefonso; en los sermones de Bernardo de Claraval que hablaban de María como principal intercesora; en las leyendas del siglo XII relativas a la fundación de 
Las sociedades cristianas emplearon las imágenes marianas para canalizar objetivos tangibles como la defensa contra todo tipo de males: vencer a los enemigos de otra religión o castigar a no creyentes, infieles y herejes en nombre de la fe, asegurar triunfos militares, obtener protección para los habitantes y las ciudades ante las pestes, enfermedades y satisfacer necesidades materiales ante los problemas de subsistencia. Tales usos basados en la creencia de su poder apotropaico y taumatúrgico parecían mantener cierta correspondencia con las invocaciones que se habían hecho primero a las figuras paganas y luego a las reliquias. ${ }^{13}$ Por el contrario, conocidas acciones contra las imágenes de los santos y la Virgen se imputan en España a musulmanes y judíos. La visión popular y la literatura medieval los muestra como los principales transgresores: mofándose, blasfemando, profanándolas o destruyéndolas. De igual modo estuvieron bajo sospecha los herejes que deshonraban a las imágenes $\mathrm{y}$ les faltaban el respeto negando las verdades reveladas por la Iglesia. ${ }^{14}$

\subsection{IMÁGENES MARIANAS MILAGROSAS EN LA RECONQUISTA DE ANDALUCÍA}

En los textos medievales encontramos numerosas narraciones que subrayan las funciones protectoras de las imágenes marianas a favor de los cristianos en las guerras de frontera. ${ }^{15}$ Algunas tuvieron fundamentos históricos legendarios y encuentran su

monasterios o santuarios ligados al culto de una imagen local, a un hecho prodigioso que las legitimaba como objeto sagrado, como "expresión visible de un nexo invisible"; en las colecciones de milagros que circularon en Europa en el siglo XIII como Las Cantigas de Santa María del rey Alfonso X el Sabio, los Milagros de Nuestra Señora del monje del monasterio de San Millán de la Cogolla, Gonzalo de Berceo, y los escritos en latín como el Liber Mariae del franciscano Juan Gil de Zamora. Véase SAnSTERre, J-M: “Actitudes occidentales á l'égard des miracles d'images dans le Aut. Moyen Age“, en Annales, Histoire, Sciences Sociales, № 53 (1998) y "La image blessé, l'image soufrante: quelques récits de miracles entre Orient et Occident (VIe-XIIe siécle)", en Sansterre, J-M y Schmitt, J-C (eds), Les images dans les sociétés medievales: pour une historie comparée, Bulletin de 1'Institute Historique Belge de Rome, No 69, Roma y Bruselas (1999).

${ }^{13}$ En las Cantigas de Santa María el propio rey Alfonso X hizo referencia a las intervenciones de María a través de imágenes animadas que adquirían capacidad de hablar, moverse y trasladarse, incluso se situó como garante de la autenticidad de esos hechos milagrosos. Véase Iogna- Prat, D, Palazzo, E y Russo, D (eds): Marie. Le culte de la Vierge dans la societé médiévale, París, 1996; Yarza Luaces, J: "Historias milagrosas de la Virgen en el arte del siglo XIII", Lombard, № 15 (2002-2003), pp. 205-245; SAnSterre, J-M y Henriet, P: "De ' 1 'inanimis imago à 1 ' omagen mui bella. Méfiance à l'égard des images et essor de leur culte dans l'Espagne médiévale (VIIe-XIIIe siècle)", en La piedad medieval: imágenes, reliquias, hagiografía. Edad Media $N^{o}$ 1. Revista de Historia, (2009), pp. 37-92; GARCía AviLÉs, A: "Imagen y ritual: Alfonso X y la creación de imágenes en la Edad Media", Anales de Historia del Arte, vol extraordinario 11-29 (2010), pp. 11-29; y para la Edad Moderna los estudios de William, C: Religiosidad local en la España de Felipe II, Nerea, Madrid, 1991 y Vizuete Mendoza, J. C y Martínez-Burgos García, P. (coords): Religiosidad popular y modelos de identidad en España y América, Universidad de Castilla La Mancha, 2000, pp. 324-342.

${ }^{14}$ Consideraciones sobre uno y otro grupo a los que se les atribuyó el desdén por los cristianos a los que calificaron de idólatras se encuentran en Las Cantigas de Santa María de Alfonso X El Sabio y en una obra escrita por el obispo Lucas de Tuy De altera vita fideique controversis adversus albigensium errores libri III (ed) Juan de Mariana, Andreas Angermarius, Ingoldstadt, 1612. Véase también GarcíA Avilés, A: "Imágenes vivientes: idolatría y herejía en las Cantigas de Alfonso X el Sabio", Universidad de Murcia, 2009

15 Rodríguez Molina, J: "Santos guerreros en la frontera" en Toro Ceballos, F. y Rodríguez Molina, J. (coords): Historia, tradiciones y leyendas en la frontera. Homenaje a Enrique Toral Peñaranda. IV Estudios de Frontera. Congreso celebrado en Alcalá la Real en noviembre de 2001, Diputación Provincial de Jaén 
equivalente en otros célebres hechos milagrosos ocurridos en el Oriente Bizantino. ${ }^{16}$ Temas y motivos similares sirvieron una y otra vez a distintas sociedades, reactualizándose reiteradamente. Un ejemplo de ello es que la concepción de complementariedad que debió existir entre lo religioso y militar afloró también en la Edad Media hispánica, como lo demuestran las noticias sobre las prácticas empleadas en Andalucía donde los habitantes transformaron los lugares estratégicos de las ciudades en puntos de veneración a la Virgen, utilizando sus imágenes como armas defensivas, colocándolas en hornacinas y capillas en el interior de las murallas, o emplazándolas junto o cerca de las puertas, o en los alcázares para proteger a todo el recinto. ${ }^{17}$

La tradición recogida en La Cantiga de Santa María 185 cuenta que entre 1271 y 1274, durante el asedio del rey de Granada y de los musulmanes de Bélmez, el castillo de Chincoya, perteneciente a la jurisdicción de Ubeda, fue principal escenario donde tuvo lugar un hecho milagroso. Los cristianos pusieron la imagen de Nuestra Señora entre las almenas con el fin de amedrentar a los moros de Granada para que abandonaran el combate. El carácter inexpugnable de la arquitectura militar se complementó con la protección y defensa garantizadas por la "presencia" de la Virgen que imprimió en los hombres que la custodiaban la fortaleza necesaria para que la plaza no cayera, y en los musulmanes el temor para que desistieran de su conquista. ${ }^{18} \mathrm{Algo}$ similar ocurrió en Jerez de la Frontera con una talla de Nuestra Señora con el niño Jesús en brazos -de tamaño natural y de muy buena factura- colocada en la puerta del Real (antiguamente de Marmolejo) "donde caballeros y gente de Jerez hacian oración para sustentar las murallas". En este caso, la leyenda no carece de importancia, aseguró el efecto de identificación entre la imagen y la figura real de la Virgen reforzando la creencia en la defensa urbana con la fe en la protección divina. Finalizada la guerra de frontera, vecinos, moradores y viajeros levantaron en dicha capilla una iglesia que, desde que se labró, fue muy frecuentada por los fieles, aumentando su devoción, adornos, fiestas y ornamentos. ${ }^{19}$

En las crónicas e historias medievales existen también múltiples ejemplos de atribución a imágenes marianas de ayuda celestial a los reyes en la batalla contra los musulmanes. Bien conocida es la leyenda de la milagrosa imagen que se vinculó a la

(2002) y Martín Martín, J. L: "La frontera como entorno legendario", en Toro Ceballos, F. y Rodríguez Molina, J. (coords): Historia, tradiciones y leyendas en la frontera...

${ }^{16}$ Por ejemplo, en períodos de guerra no fue extraño que las ciudades se protegieran colocando íconos en las murallas así lo ilustra la orden dada en el año 626 por Sergio, el patriarca de Constantinopla para pintar las imágenes de la Virgen María en las puertas de la ciudad a fin de que actuaran como guardianas ante el peligro de los ávaros y la mediación mariana a través de una pintura atribuida al evangelista San Lucas que, colocada en la muralla se le adjudicó el naufragio de los navíos musulmanes que cercaban la urbe para invadirla. RuBIN M.: "Imágenes de la Virgen María", en II Jornadas Complutenses de Arte Medieval (2010), pp. 109-124.

${ }^{17}$ Espinosa de los Monteros, P: Segunda parte de la Historia y grandezas de la ciudad de Sevilla, Sevilla, 1630 , p. $142 \mathrm{v}-143$

${ }_{18}$ Morales, S: Castillos y murallas del Santo Reino de Jaén, Instituto de Estudios Giennenses, Jaén, 1958, p.67; Eslava Galán, J: "Las fortificaciones medievales de Andújar", Boletín del Instituto de Estudios Giennenses (1990).

${ }^{19}$ Rallón, E: Historia de la ciudad de Xerez de la Frontera y de los reyes que la dominaron desde su primera fundación, t. II, Universidad de Cádiz, 1998, cap. XIII, p. 29 
Reconquista de Andújar en 1225 y Baeza en 1227: la Virgen de la Cabeza. ${ }^{20}$ Dos autores han trazado el desarrollo de su devoción y culto: una versión se conoce a través del manuscrito redactado en 1633 por el escribano público Juan de Ledesma y la otra por la obra escrita en 1677 por el alguacil mayor del Santo Oficio de la Inquisición de Andújar, Manuel Salcedo Olid. ${ }^{21}$ El primero la ha destacado entre otras tantas imágenes de santuarios del arzobispado de Sevilla, Granada, Málaga, Jaén y Extremadura, describiéndola de la siguiente manera:

"era como todas las demás milagrosas y antiguas, de talla pequeña, de siete doceavos de estatura, de divino rostro proporcionado con el cuerpo algo aguileño. Tiene al niño Jesús en el brazo izquierdo y parece que está dando una rosa su Madre que tiene en la mano diestra".22

El segundo, en cambio, ha enfatizado su antigüedad y condición de reliquia al revelar que cuando San Pedro visitó a los obispados de España había llevado consigo imágenes de la Virgen Santísima que transportó desde Antioquía a Roma, una de ellas hecha por la mano del evangelista San Lucas, la Virgen de la Cabeza, dejó el apóstol en manos de San Eufrasio para consuelo de los fieles andaluces. ${ }^{23}$ Desde entonces San Eufrasio introdujo esta devoción en tiempos en que fue obispo (año 44 d. C) y le dedicó un oratorio con título de Asunción de Nuestra Señora, lugar en el que fue enterrado después de su martirio.

En el año 716, después de caer esta ciudad bajo la dominación musulmana, los cristianos trasladaron la imagen-reliquia para esconderla junto a una campana "para que se supiera que en todo tiempo había estado en iglesia de cristianos". ${ }^{24}$ Según las creencias a su intercesión se atribuyó la Reconquista de Baeza, razón por la cual desde entonces se acrecentó su devoción, formándose bajo su advocación una cofradía en la que participaron casi todos sus vecinos y pobladores, y luego en virtud de la difusión de sus milagros se fundaron otras 85 cofradías en 12 ciudades y 53 villas. Así fue Andújar la que primero se transformó en centro cultual mariano proyectando su radio de acción a territorios circunvecinos que quedaron integrados para celebrar su fiesta. ${ }^{25}$

A otras imágenes la tradición las señala como traídas a la Reconquista de las ciudades andaluzas en recuerdo de la piedad y devoción de la monarquía, o que se hicieron conocidas como imágenes milagrosas de batalla. Estas tienen su más fiel exponente

20 GonzÁlez Jiménez, M:, “Devociones marianas y repoblación. Aproximación al caso andaluz”, Actas das Jornadas Luso-Espanholas de Historia Medieval, Porto (1988)

21 Ledesma, J. de: Imágenes de María Santísima Nuestra Señora en esta ciudad de Sevilla y su reinado, y distrito del Andalucía y Extremadura, donde están estos santuarios y algunas noticias de Sevilla y de su Santa Iglesia, Sevilla, 1633

22 Ibidem., p. 69

23 Salcedo Olid, M: Panegírico historial de Nuestra Señora de la Cabeza de Sierra Morena, Madrid, 1677, cap. VIII, p. 74 y cap. X, pp. 93-95

${ }^{24}$ Ibidem, Libro II, p. 213

25 Terrones de Robres, A: Vida, martirio y milagros de San Eufrasio obispo y patrón de Andujar. Origen y excelencias desta ciudad. Privilegios de que goza y varones insignes en santidad, letras y armmas que ha tenido, Granada, 1657, pp. 178v-179. 
en la Virgen de los Reyes que garantizó la recuperación de Sevilla y fue objeto de devoción de Fernando III y Alfonso X. Son varias las versiones que circulan en torno a su origen, unas dicen que el rey santo recibió grandes favores por intercesión de Santa María y por ello convocó a escultores para que tallaran una obra lo más fiel posible a la imagen aparecida en sus visiones; otra leyenda asegura que la imagen fue realizada en Francia y donada a Fernando III por su primo francés el rey Luis IX, o que procedía de Alemania y fue enviada por el emperador Federico II, mientras una tercera cuenta que acompañaba a Fernando III en el real -donde se le erigió una ermita que se transformó desde entonces en lugar sagrado- y con ella presidió su entrada triunfal en la conquista de Sevilla en $1248 .{ }^{26}$

Pero los autores incluso fueron más allá de estas explicaciones y le dieron un origen sobrenatural y "maravilloso", entre ellos el abad mayor del Cabildo de Beneficiados de Sevilla, Alonso Sánchez de Gordillo, quien entre fines del siglo XVI y principios del XVII escribió acerca de las imágenes que se reverenciaban en los templos de la ciudad. Así señaló que los artífices de la Virgen de los Reyes no eran oficiales de obra comunes, sino ángeles del cielo, "dos gallardos mancebos que parecían extranjeros" quienes dijeron a Fernando III que confiando en Dios darían buena cuenta de la voluntad real haciendo la imagen de la Virgen. ${ }^{27}$

Una noche, durante el asedio a Sevilla, el rey Fernando III se postró ante la Virgen de los Reyes -una talla de madera de alerce de unos 1 metro 73 centímetros, con movimiento, que representaba a María con atributos y ropaje de la realeza, junto al niño sentado en sus rodillas- para pedirle auxilio, quien le habló de la constante protección que recibiría en su imagen pintada de la Antigua que permanecía oculta en una pared de la mezquita. Desde que se cumplió la promesa de su victoria, el rey impulsó la devoción y culto hacia esa sagrada imagen que se convirtió en intercesora de las grandes hazañas cristianas. ${ }^{28}$

Existen también testimonios sobre el carácter sagrado de la bienaventurada imagen de la Virgen de la Antigua arrebatada a los cristianos por los musulmanes. De ella dice la tradición popular que "No había quien se atreviera a destrozarla, porque que-

26 Ortiz de ZúNiga, D: Anales eclesiásticos y seculares de la muy noble y muy leal ciudad de Sevilla Metrópoli de Andalucía que contienen sus mas principales memorias desde el año 1246 en que emprendió conquistarla del poder de los moros el gloriosísimo rey San Fernando III de Castilla y León hasta el de 1671 en que la católica Iglesia le concedió el culto y título de Bienaventurado, Madrid, 1795, T I, Libro I, p.16

27 SÁnchez Gordillo, A: Memorial de las religiosas estaciones que frecuenta la devoción sevillana. Con adiciones del canónigo D. Ambrosio de la Cuesta y del copista anónimo de 1737 (MS). Estudio preliminar, edición de textos y notas por Jorge Bernales Ballesteros, Patronato Ricardo Pantú Leal del Concejo de General de Hermandades y Cofradías de Sevilla, 1983, pp 507-521.

28 Sobre el estrecho vínculo establecido entre Fernando III y la imagen de la Virgen escribió el viajero alemán Jerónimo Münster: "Siempre llevaba consigo esta imagen al campo de batalla, y la tenía en grande veneración, y la adornó en la cabeza con una corona de oro purísimo, esmeraldas, perlas y otras piedras preciosas... La mayor parte de las veces derrotó a los moros por virtud de la bienaventurada Virgen" en Viage por España y Portugal 1494-1495. Prólogo de Manuel Gómez Moreno y traducción de José López Toro, Colección Almenara, Madrid, 1995, p. 65. También Diego Ortiz de Zúñiga comentó que la imagen de la Virgen de los Reyes formó parte de numerosas procesiones: en 1337 presidió una con motivo de la enfermedad y curación del rey y en 1504 otra organizada por el cabildo eclesiástico, para dar gracias por el fin de los fenómenos naturales que habían afectado a la ciudad el viernes santo. Anales eclesiásticos y seculares..., T. III, Libro XII, pp. 192-193 
daban ciegos, sordos y tullidos", ${ }^{29}$ y las crónicas cuentan que la Providencia Divina prevaleció sobre los esfuerzos de los moros que no pudiendo deshacerse de su imagen la ocultaron tapiándola, temerosos de los rayos de luz resplandeciente que despedía.

Pese a que se trataba de una pintura de estilo romano-bizantina que se cree se remontaría a la época visigótica, las leyendas sobre su antigüedad y sacralidad cobraron fuerza, apoyándose los autores en signos que la calificaban como "imagen divina" y de "origen maravilloso". ${ }^{30}$ Así lo sostuvieron historiadores como Rodrigo Caro, Alonso Morgado y Diego Ortiz de Zúñiga hasta que en el siglo XVIII el P. Antonio de Solís presentó los fundamentos necesarios para probarlos. Considerando que el artífice de la sagrada efigie puso en ella varios símbolos para instruir a los cristianos (en la mano derecha de la Virgen una flor, la rosa, sin espinas como el más bello adorno de los huertos y el paraíso terrenal para decir que de la misma forma que ésta dominaba entre las flores, María estaba libre de todo pecado y era la Reina entre las Vírgenes; el color purpúreo de la rosa, propio de los reyes, para mostrar que era por excelencia el de María, Reina y honra de todas las mujeres; la mano diestra del niño Jesús en ademán de bendecir y en la siniestra un pajarillo para representarlo como criador de todas las cosas, como autor y árbitro de la vida y la muerte) concluyó que la imagen debía pertenecer a los primeros tiempos de la Iglesia. Asimismo, afirmó que aquella bella copia de gran perfección no pudo haber tenido autor humano y que el cielo la había preservado de todas las injurias de los tiempos con especial protección y milagro. ${ }^{31}$ Así pues, la creencia muy extendida en esta imagen milagrosa mantuvo viva la devoción a la Virgen con la creación de la Hermandad de Caballeros de Nuestra Señora de la Antigua en el siglo XVI, y especialmente en 1521 en los carmonenses que, afligidos por la falta de lluvias que dejaban sus campos yermos y empobrecidos, marcharon como penitentes en rogativa un 11 de mayo hacia la catedral de Sevilla, donde fueron escuchados por el cielo que los alivió con torrentes necesarios para la producción de la tierra.

\subsection{IMÁGENES MARIANAS MILAGROSAS Y PROTECTORAS DE CIUDADES Y COMARCAS}

Otra de las devociones más antiguas que se conocen en el Obispado de Sevilla es la que se le ha tributado a la Virgen del Valle. Las noticias que se tienen sobre su imagen sitúan su origen en la donación que el papa Gregorio Magno hizo a San Leandro, quien cuando era obispo en la sede hispalense, entregó este "celestial regalo" -que se cree hecho por San Lucas- a San Fulgencio, obispo de Ecija, y éste a su hermana Santa Florentina, fundadora del convento de Nuestra Señora del Valle y de muchos otros cenobios que se rigieron por la regla de San Benito en Andalucía. Ese lugar, situado en las cercanías de Ecija, aguas abajo del río Genil, fue asolado por los musulmanes durante la invasión a España pero siguió gozando de gran reverencia por parte de los

29 MÜNZER, J: ob. cit., p. 65.

30 SÁnchez Moguer, A: Historia de Nuestra Señora de la Antigua patrona de Sevilla en cuya Santa, Metropolitana y Patriarcal Iglesia se venera, Sevilla, 1868.

31 Solís, A: Historia de Nuestra Señora de la Antigua venerada en la Santa Metropolitana y Patriarcal Iglesia de Sevilla, 1739, cap. VI, pp. 73-77 y cap. VII, pp. 77-89 
pobladores cristianos, pues allí se conservó la antigua imagen sagrada, por ser el sitio donde padecieron martirio las monjas y donde fue sepultada en el año 633 la Santa.

Tres tradiciones distintas se han difundido acerca de la imagen de la Virgen del Valle: una habla de su culto permanente por parte de los mozárabes, otra que fue ocultada por las monjas en un torreón del convento y una tercera de su invención milagrosa. Sin embargo, todas las leyendas tuvieron un denominador común: la propagación de la devoción a través del linaje Portocarrero. El 7 de octubre de 1486, por licencia y bula del papa Inocencio VIII, la iglesia y ermita del antiguo convento pasaron del Dr. Juan de Medina, prior de las ermitas del arzobispado de Sevilla, al cuidado de Luis Portocarrero, VII señor de la Villa de Palma, Comendador de Azuaya, Caballero de la Orden de Santiago y alcalde de la ciudad de Ecija, quien las integró al nuevo monasterio fundado bajo la dirección de la Orden de los Jerónimos, estableciéndose en él religiosos procedentes del monasterio sevillano de San Isidoro del Campo. Dicha institución, de vida religiosa reformada a la observancia desde 1428, había comenzado a cobrar mayor prestigio en la Corona de Castilla tras recibir señalados favores de los monarcas, así su encumbramiento se tradujo en la dirección del santuario de la Virgen de Guadalupe, en la elección de los monjes para San Lorenzo del Escorial y, con la transferencia establecida por el papa Pío en 1569 se agregaba la custodia de la Virgen del Valle. ${ }^{32}$ Desde entonces, la citada Orden, como propagadora del culto de la sagrada imagen mariana, recibió importantes dotaciones: de la familia Portocarrero $50.000 \mathrm{mrs}$ y 20 cahíces de trigo de renta anual a cambio de privilegios de patronazgo y enterramientos, además de limosnas, propiedades de vecinos de Ecija y derechos de concesión de sepultura a nobles y caballeros. ${ }^{33}$

En la segunda mitad del siglo XVI, una obra de Fray Francisco Gonzaga, obispo de Mantua, recogió los relatos milagrosos sobre esta imagen que pasaron a los escritos de otros historiadores. ${ }^{34}$ Por ejemplo, el Padre Rodrigo Yepes, miembro de la Orden y residente por dos años en el monasterio, como buen conocedor y testigo de vista, ha dejado constancia de la devoción a la santa imagen, sobre todo de gente humilde que aventajaba a los ricos "que con sus pecados y riquezas en cosas de devoción son tibios, en la limosna cortos y en la adoración a los santos secos e indevotos". Así escribió que muchos fieles iban desde la ciudad hasta el santuario que distaba $1 \mathrm{~km}$, descalzos o de rodillas para ver la Virgen, y sobre todo las mujeres pobres trabajaban hilando para ofrecer limosnas con el fin de que se dijeran misas en el altar dedicado

32 A partir de 1428 al instaurarse la reforma por Fray Lope de Olmedo, se fundaron 7 monasterios, 6 de ellos en Andalucía: San Isidoro del Campo, Santiponce, Santa María de Barrameda, San Lúcar de Barrameda, San Miguel de los Angeles en Sanlúcar La Mayor y Santa María de Gracia en Carmona.

33 López de CÁRdenas, D: Historia crítico cronológica de la Soberana Imagen de María Santísima con el título portentoso del Valle, Patrona de la ciudad de Ecija y Protectora de esta Provincia de Andalucia, Ecija, 1817. Véase García León, G: "Notas para la historia del Monasterio de San Jerónimo del Valle", Actas del III Congreso de Historia: Ecija en la Edad Media y Renacimiento, Ayuntamiento de Ecija, Universidad de Sevilla, Fundación El Monte (1993), pp. 422-437; Martín OjedA, M. y García León, G: La Virgen del Valle de Ecija, Ecija, 1995; Miura Andrades, J. M: "El milagro de Nuestra Señora del Valle. Análisis de una tradición hagiográfica”, en Actas del III Congreso de Historia Ecija..., Fundaciones Religiosas y Milagros en la Écija de fines de la Edad Media Gráficas Sol, Écija, 1992 y "Milagros y conventos en la Andalucía medieval", en Cuadernos del Cemyr (Centro de Estudios Medievales y Renacentistas) Universidad de la Laguna, vol. 1 fasc. $1,(2003)$.

34 Fray GonZaga, F: De origine et progressio ne serephicae religionis franciscanae, Roma 1587 y 1602 
a la Madre de Dios que daba consuelo y remedio a sus necesidades, obrando muchos milagros con enfermos, cojos y cautivos. Tales noticias se conocen por los exvotos que dejaron colgados en las paredes de la iglesia (esculturas de cera que representaban los miembros humanos curados, cadenas de cautivos rescatados, armas de valientes soldados, banderas de moriscos arrebatadas por los ecijanos en la guerra de las Alpujarras) testificando así los dones recibidos y constituyendo una propaganda nada despreciable para el santuario. Por estas razones Ecija tomó a la Virgen del Valle como Señora y protectora de la ciudad, considerándola sus habitantes "bien de bienes y suma riqueza", "consuelo de afligidos, norte y guía del cielo". ${ }^{35}$

No han faltado otros signos evidentes de difusión de esta devoción mariana. Gracias a la Orden de los Jerónimos, a las cofradías hospitalarias dedicadas a Nuestra Señora del Valle (que se unió a la de San Cristóbal y Santiago de los Caballeros en 1515) y a la Hermandad de la Esclavitud de Nuestra Señora del Valle fundada por Francisco Martín de la Vega (s. XVII). Su fiesta anual el 8 de septiembre, aprobada por el cabildo municipal - estrechamente vinculado a la cofradía y a la imagen- cobró vitalidad a partir del 29 de agosto de 1584, así como las procesiones y rogativas que empleaban la imagen para dar gracias y pedir por las necesidades de la ciudad, como sucedió con los traslados a la parroquia de Santa Cruz entre 1580 y 1582 ante las crisis agrarias, epidemias, plagas, problemas climatológicos y hambrunas. ${ }^{36}$

También en su obra manuscrita Alonso Fernández de Grajera ha detallado diversas prácticas religiosas cumplidas en el camino a la santa casa de la Virgen que se convirtió en centro de peregrinaciones de los reyes y población en general, sobre todo a partir de 1470 en que el papa Paulo II sancionó una bula de 100 años de indulgencia para quienes lo visitaran en su festividad:

“...de noche i de día no çesan de caminar infinitos marineros arrodillándose (sic) a las cruces i umilladeros del santo camino, otros con cruces y barras de ierro a cuestas, otros descalços i con otras inbenciones peniténciales, otros con ásperas disciplinas derramando sangre de sus cuerpos bañando la tierra i con ardientes lágrimas de sus hojos." ${ }^{37}$

La viva fe con que se extendió la devoción a esta Virgen también se reflejó en las obras de Diego Ortiz de Zúñiga y el jesuita P. Martín de Roa. Ambos han señalado que el convento de San Francisco de Sevilla tuvo su origen en 1403 a partir de la intervención milagrosa de Nuestra Señora que auxilió, tras la invocación de una madre viuda devota de Ecija, a un niño que había caído en un pozo de agua. Con tanta súplica y ruego se había dirigido a la Virgen que en agradecimiento de su favor le concedió casas para la fundación del convento de monjas dominicas con advocación a Nuestra

35 Fernández de Grajera, A. Historia de la ciudad de Ecija. (1615-1620). Estudio introductorio y transcripción Mariano Oroño López, Fundación el Monte, Sevilla, 1995; Florindo, A: Adición al Libro de Ecija y sus grandezas, Ecija, 1631

${ }^{36}$ YePES, R: Historia de la gloriosa Santa Florentina, hermana de San Leandro y San Isidoro, arzobispos de Sevilla y de San Fulgencio, obispo de Ecija. En que se replican muchas antigüedades de España y otras cosas de varia doctrina. Y una genealogía cumplida de los Reyes de España trayda desde antes de Sancta Florentina hasta ahora, San Jerónimo el Real de Madrid, 1584, cap. VI, pp. 21v-22 y cap. VII, p. 23.

37 Fernández de Grajera, A: ob. cit., cap. VI, p. 69 
Señora del Valle. ${ }^{38}$ Hacia 1416 un nuevo hecho se produjo en la iglesia parroquial de San Román, cercana al convento. Un sacristán consideró inútil a una antigua imagen de Nuestra Señora, quiso romperla para alentar el fuego con la madera pero escuchó una voz que se quejaba de su atrevimiento. Conocido el milagro por el arzobispo, deán y cabildo, la imagen fue trasladada al convento de Nuestra Señora del Valle para ser venerada convenientemente. ${ }^{39}$

Y en Jerez de la Frontera, el monasterio de San Agustín, localizado fuera -pero próximo a la ciudad- cuyo patronazgo correspondía a un caballero jerezano, ha sido frecuentado en todo tiempo no sólo por su hermoso edificio, templo y capilla, sino fundamentalmente por la posesión de dos sagradas imágenes de antigua veneración. En 1532 recibió una imagen pintada con título de Santa María de Guía cuya devoción se originó en el camino del Puerto de Santa María, al que le dio el nombre esta "verdadera estrella de mar" que orientaba y protegía a los viajeros que emprendían la ruta hacia las Indias Occidentales. ${ }^{40} \mathrm{Y}$ en 1623 fue depositada allí otra imagen llamada Santa María del Socorro, por donación de Don Martín Alberto Dávila Cabeza de Vaca, gracias a la cual la ciudad y su comarca se beneficiaron de muchos milagros, especialmente en situaciones difíciles como la falta de agua, pestes y enfermedades. ${ }^{41}$

\subsection{TRANSLATIO E INVENTIO DE IMÁGENES MILAGROSAS}

Los relatos de las crónicas e historias se refirieron también a un origen incierto pero suficientemente antiguo de las imágenes marianas para recrear el pasado cristiano de las sociedades de frontera que habían ocultado o trasladado sus objetos sagrados más preciados durante la guerra, con el fin de salvaguardarlos de los musulmanes que habían tomado ciudades arrasando con las iglesias, destruyendo altares y profanando imágenes. Sin embargo, cuentan que la Reconquista cristiana trajo consigo el "reencuentro" con ellas a través de la inventio, según el cual el hallazgo no fue producto de una búsqueda intencional o arqueológica, sino de descubrimientos de carácter maravilloso, extraordinario, de la revelación divina. ${ }^{42}$

Un particular hallazgo de la imagen de la Virgen que había sido venerada por los reyes visigodos y salvada por los cristianos se produjo en el siglo XIII, durante el reinado de Alfonso X. Bartolomé Jiménez Patón cuenta que unos labradores, de los primeros que repoblaron Jaén después de 1246, encontraron -plantando un árbol

38 RoA, M: Ecija, sus santos, su antigüedad eclesiástica y seglar, Sevilla, 1629, Libro III, cap. VII, pp. 143-144. Ortiz de Zúñiga afirma que fueron beatas en comunidad que en 1649 se integraron al convento de religiosas de San Francisco, ob. cit., T. II, Libro IX, p. 294

39 OrTIZ DE ZúÑIGA, D: ob. cit., T. II, Libro X, pp. 352-353

${ }^{40}$ La misma contaba ya con una larga tradición milagrosa documentada en las Cantigas de Santa María $328,356,357,358,359,364,366,367,368,371,372,375,376,377,378,379,381,382$, 385, 389, 391, 392, 393 y 398.

${ }^{41}$ RoA, M. de: Santos Honorio, Eutichio y Esteban, patronos de Jerez de la Frontera. Nombre, sitio y antigüedad de la ciudad. Valor de sus ciudadanos, Sevilla, 1617, cap. XIV, pp. 45-45v

42 Velasco Maillo, H. M: "Las leyendas de hallazgo y de singularización de imágenes marianas en España. Una aproximación a la categoría de imagen-persona”, en González Cruz, David (coord), Religión y costumbres populares en Iberoamérica. Actas del I Congreso Internacional celebrado en Almerte El Rocío, España (1999). 
extramuros de la ciudad, cerca de la puerta de Martos- una campana y en un hueco la bendita imagen que se había dejado oculta por 535 años: "Hincándose de rodillas, soltándoseles las lágrimas de contentos, adoraron y dijeron las gracias por el inestimable tesoro que alli les había Dios manifestado". "Los descubridores repararon mucho en su llamativa corona, por eso la llamaron "Nuestra Señora de La Coronada". Tras tomar conocimiento de lo sucedido, el obispo la hizo llevar en solemne procesión a la iglesia hasta que se le edificase una ermita decente. Desde entonces la imagen realizó muchos milagros en la frontera como auxiliadora de los cautivos, se cree que intercedió enviando a los ángeles al reino de Granada para liberar a los prisioneros cristianos y a favor de devotos padres, mujeres e hijos que acudían a ella a pedirle que los protegiese de los musulmanes. Así pues, en señal de esos hechos colgaron en su templo los símbolos de las numerosas redenciones (grilletes rotos y cadenas cortadas). Creció tanto la devoción a esta imagen que fundaron una cofradía militarizada, de ballesteros de la Coronada y le edificaron junto a la ermita una torre y fortaleza donde los pobladores labradores se refugiaban de las incursiones musulmanas. ${ }^{44}$

En agradecimiento de tantas mercedes recibidas de la Virgen se hicieron importantes donaciones de bienes y heredades a la ermita, convirtiéndose en una de las más ricas de Andalucía. Fue entonces cuando para mejor veneración de la imagen, en tiempos del obispo Don Alonso de la Fuente el Sauce, se decidió fundar allí el convento de Nuestra Señora del Carmen de religiosos observantes. Para la nueva fábrica, se emplearon todos los medios económicos, incluso se reemplazó la imagen de la Virgen por otra más bella y de mayor tamaño. Pero según las creencias "Dios no quiso que la devoción a la antigua y pequeña imagen de la Coronada que se había quitado del altar se desvaneciera y olvidara", por ello ejecutó nuevos milagros con la aparición de la Virgen a un canónigo "de mucha ciencia y costumbres aprobadas" para anunciarle que la sacasen del lugar donde estaba para volverla a su antiguo sitio. Cumpliendo con el mandato los frailes fueron en su búsqueda y encontraron a la imagen enhiesta, saliendo de su divino rostro rayos de luz maravillosos. Todos quedaron avergonzados de la poca estima que habían demostrado a la celestial reliquia y la trasladaron en procesión al lugar donde pertenecía, cantando himnos, antífonas y versos de alabanza. Esas señales acreditaron la sacralidad de la imagen, reafirmaron y avivaron la devoción, las misas y las fiestas. ${ }^{45}$

Entre los siglos XVI y XVII fueron documentados otros importantes hallazgos. En 1592 Martín Jimena Jurado escribió acerca del que se produjo con la imagen de la Virgen de la Peña, talla que apareció en el camino de Jaén, en una cueva en donde había sido escondida por los cristianos. Por su parte, Francisco de Vilches catalogó como el lugar más famoso de la ciudad de Jaén el alcázar donde las monjas del

43 JimÉnez PAtón, B: Historia de la antigua y continuada nobleza de la ciudad de Jaén, muy famosa, muy noble y muy leal, guarda y defendimiento de los reinos de España y de los varones famosos hijos della, Jaén, 1628, cap. XIV, p. 60

44 Ibidem. pp. 61-62. GonzÁlez DÁvila, G: Teatro eclesiástico de las Iglesias Metropolitanas y catedrales de los Reynos de las dos Castillas. Vidas de sus arzobispos y obispos y cosas memorables de sus sedes. T I que contiene las Iglesias de Santiago, Sigüenza, Jaén, Murcia, León, Cuenca, Segovia y Valladolid, Madrid, 1645 , p. 218.

45 Jiménez Patón, B: ob. cit., p, 62 
convento de Santa Catalina habían visto luces, escuchado música de campanas, de instrumentos muy acordados y voces muy suaves durante la celebración de fiestas religiosas, dando lugar en 1628 y 1629 a procesiones y en 1639 a excavaciones que terminaron con el descubrimiento de un "monte sagrado" donde encontraron los restos de santos mártires y junto a ellos la imagen de la Virgen de los Mártires con el niño Jesús en brazos. ${ }^{46}$

También en Baeza se registran noticias sobre inventio que han gozado de gran predicamento popular, unas están referidas a la imagen de Nuestra Señora del Rosario ocultada durante la invasión musulmana y hallada después de la Reconquista, en un socavón de una casa arruinada, junto a la puerta de Jaén, ${ }^{47}$ otras nos remiten a la imagen de Nuestra Señora del Alcázar, talla románica que acompañó a las tropas de Alfonso VII en la Reconquista y que se convirtió en patrona de Baeza. En su efímera ocupación de la ciudad fue guardada -por ser grande y pesada para llevarla- bajo tierra y cubierta con una campana, llamada la Beltrana, cuando los cristianos tuvieron que abandonar la ciudad que pasaba otra vez a poder de los musulmanes en 1157. Con su conquista definitiva en 1227 se produjo el milagro del hallazgo de la imagen en el alcázar tras lo cual ese lugar, donde había existido una primitiva mezquita, se convirtió en parroquia de Santa Ana, llamada luego de Santa María y en 1401 designada ya Colegiata por el obispo Fernández de Narváez tomó el título de Nuestra Señora del Alcázar. ${ }^{48}$ En este caso fue el P. Rus Puerta quien actualizó su devoción religiosa al escribir cómo en torno a 1643 se reavivó su renombre por un milagro ocurrido en la casa de Baltasar Carvallo, cerca del monasterio de la Encarnación de religiosas Carmelitas Descalzas. El mismo tuvo lugar a favor del hijo de este albañil que cayó a un pozo profundo y a pesar de varios intentos de la gente que tiraba de la soga para subirlo y sacarlo en un cubo, volvía al fondo. Cuando el padre bajó a rescatarlo, el niño contó que una Señora vestida de blanco lo sostuvo y ayudó para mantenerlo a flote. Todos reconocieron que había sido la Virgen del Alcázar, a quien la madre del niño había invocado. ${ }^{49}$

Otros testimonios hacen referencia a la aparición milagrosa de la imagen de la Virgen Nuestra Señora de Sevilla debajo de una retama o escobera, en un monte que los catalanes llamaban "Ginesta", donde había sido llevada en tiempos de la guerra de frontera. Alonso Morgado escribió: "por orden del cielo fue restituida al mismo y antiguo lugar donde estuvo en tiempo de los godos, la iglesia de San Julián, una de

46 Vilches, F. de: Santos y santuarios del Obispado de Jaén y Baeza, Madrid, 1653, p. 251. Véase Rodríguez Moñino-Soriano, R: Aproximación a la Historia eclesiástica de la ciudad de Baeza (Jaén). Del esplendor renacentista y barroco a la crisis liberal del siglo XIX. Diputación provincial de Jaén, Instituto de Estudios Giennenses, 2000

47 Rodríguez Molina, J (Dir): Historia de Baeza, Universidad de Granada, 1985

48 Rodríguez Moñino Soriano, R: ob.cit, p. 51.

49 Rus Puerta, F. de, Historia eclesiástica del reino y obispado de Jaén. Primera parte que contiene sus principios y progresos en la religión cristiana. La predicación de los santos apóstoles Jacobo, Pedro, Paulo. Los santos y mártires así de Arjona, como de Baexa y otros lugares. Los obispos de quien se halla memoria. La Historia, tradición y antigüedad de la Santa Verónica. Sitios de lugares antiguos con otras antigüedades dignas de ser sabidas desde el siglo I de la Iglesia cristiana hasta el duodécimo, Jaén, 1634 
las más frecuentadas de Sevilla donde ha hecho muchos milagros". ${ }^{50}$ Por su parte, Pablo Espinosa de los Monteros da cuenta de otro hecho vinculado a la advocación de la Virgen de Guadalupe, en tiempos del pontificado de Gregorio Magno. Este papa dispuso enviar una imagen de la Virgen -que se encontraba en su oratorio y había obrado muchos milagros durante la peste en Roma- al arzobispo San Leandro de Sevilla. Su traslado se hizo "con decente pompa y acompañamiento de sacerdotes" superando las tempestades que atravesó el navío durante la travesía pues confiaron devotamente en las señales resplandecientes de aquella "Estrella de mar, Reina y Señora" que apartó el peligro de las olas. Desde que la imagen llegó a la ciudad (se cree que a la Iglesia Metropolitana) la liberó de las herejías y le propició numerosos favores y bienes. Sin embargo, tras la conquista musulmana los clérigos llevaron consigo la imagen junto a otras reliquias para salvarlas de las injurias de sus enemigos, así iniciaron un viaje sin destino hasta que llegaron "por divino acuerdo" a un lugar escondido entre sierras ásperas y fragosas, cerca del río Guadalupe, donde sólo moraban fieras y animales silvestres. En un sitio que parecía seguro, una cueva que tenía forma de iglesia y que estaba cerca de una sepultura en piedra, permaneció la imagen hasta tiempos del rey Alfonso XI.

Alrededor de 1330 "fue voluntad de Dios querer descubrir al mundo el tesoro celestial que estaba guardado, permitiendo que un pastor encontrara la imagen para mejor alivio de las calamidades pasadas". Tras su aparición solicitó que se anunciara a la Villa e iglesia de Cáceres el milagro para que buscaran la imagen enterrada e hicieran capilla en su memoria. El culto se desarrolló a partir de las grandezas que realizó curando enfermos, lanzando demonios, consolando afligidos. De su sagrada imagen -que es de una vara de estatura, con corona, de rostro moreno y hermoso, con el niño a su lado derecho y en el izquierdo el cetro- se dice que parece "fábrica de cielo". Generalizada esa creencia, Alfonso XI adornó la imagen con preciosas joyas y trofeos de sus victorias militares, animó su devoción y visitó la ermita que puso bajo su patronato. Gracias a la ardiente devoción de príncipes y señores que con su piadosa generosidad agradecieron su intercesión, el lugar llegó a contar con doce capillas y abundantes rentas, se transformó en suntuosa iglesia parroquial capaz de recibir a peregrinos de todas partes. ${ }^{51}$ A cargo de los religiosos de la Orden de San Jerónimo, esa casa que custodiaba la santa imagen se fue engrandeciendo con la concurrencia de fieles, con la apertura de sendas y caminos para que pudieran transitar hacia el santuario, cuyo trayecto bordeaban también otras casas de oración y ermitas. ${ }^{52}$

También el monasterio de Nuestra Señora de la Merced de Jerez de la Frontera que "en grandeza de casa, templo y capillas compite con los mejores", custodió entre sus muros la antigua imagen de la Virgen del mismo nombre, hallada milagrosamente. Martín de Roa ha señalado que su devoción se extendió entre naturales y forasteros,

50 Morgado, A: Historia de Sevilla en la qual se contienen sus antigüedades, grandezas y cosas memorables en ella acontecidas, desde su fundación hasta nuestros tiempos, Sevilla, 1587, Libro IV, cap. IX, pp. 116-116v.

51 GonzÁlez Crespo, E: Colección documental de Alfonso XI. Diplomas reales conservados en el Archivo Histórico Nacional Sección de clero. Pergaminos, Universidad Complutense, Madrid, 1985, pp. 469-470

52 Espinosa de los Monteros, P: Primera parte de la Historia antigüedades y grandezas de la muy noble y muy leal ciudad de Sevilla, Sevilla, 1627, Libro III, cap. I, p. 108v-112v y cap. II, pp. 11v-113. 
"en los corazones de todos por los particulares favores que en los trances más desasuziados han recibido de su mano", así pues afirmó que "es maravilloso el concurso, no sólo de la ciudad, sino también de los lugares vecinos que con igual piedad i alegría se junta a celebrar sus festividades". ${ }^{53}$ Asimismo, otro monasterio, el de Santo Domingo fue el "elegido por el cielo" para ser sitio donde permanecería la imagen de Nuestra Señora con título de la Consolación, hallada milagrosamente en la mar por un caballero genovés que viniendo a Cádiz vio cerca de la ciudad una luz en el mar y acercándose la halló en una galerita pequeña, como hecha para este propósito, con una candela encendida delante. De ella oyó una voz que le decía "Llévame a la casa de los Predicadores", y obedeciendo la entregó al monasterio. Allí "tiene especial devoción y concurso de gente que ha sido honrada con millares de beneficios en tiempos y necesidades desasuciadas". ${ }^{4}$

Otro caso es el de la imagen de Santa María de la Salud hallada en 1665 dentro de un pozo. Un día que araban la tierra la descubrieron Simón de Toro y Bartolomé de la Peña, vecinos de Córdoba -del alcázar viejo frente a la puerta de Sevilla, extramuros de la ciudad-. A esta milagrosa imagen que cobró renombre por curar enfermos se le construyó en 1673, sobre los restos de un edificio romano, una capilla que fue lugar muy venerado porque se cree que allí estuvo el monasterio de San Ginés, donde fueron sepultados algunos mártires. Otra imagen de madera policromada de casi un palmo de Nuestra Señora del Pozo junto al niño -que porta una bola del mundo y ofrece a su madre una fruta irreconocible- ambos coronados, se halló en 1685 en una ermita de San Rafael, en la casa del Presbítero Andrés de las Roelas. Y a dos leguas de Córdoba en un pilar o pozo de una hacienda del Real Convento de San Pablo se halló también milagrosamente la imagen de Nuestra Señora del Pilar. ${ }^{55}$ Con tantos ejemplos milagrosos, el autor elogió a la tierra de Córdoba:

"Ciertamente admira ver que solo en Córdoba haya tantas célebres Imágenes aparecidas, y milagrosas, cuyo número excede sin duda a otras Poblaciones del mundo. Bendito sea el Señor, que tantas mercedes le hizo, y nos hace a los que nos creó en este (por tantos títulos suyo) Pais: y bendita sea la Madre de Misericordia, que quiso con tantas pruebas demarcar por suyo el País, donde antiquísimamente se le tributan tantos cultos." 56

\subsection{APARICIONES DE LA VIRGEN Y SUS IMÁGENES}

A Fray Salvador Baptista Arellano, perteneciente a la orden Tercera de San Francisco, debemos la publicación de los celestiales favores obrados por la imagen de la Virgen de Gracia, de la villa de Carmona. Este autor, gravemente enfermo y desahuciado por los médicos, escribió sobre esta "divina y soberana Señora" que milagrosamente

${ }^{53}$ RoA, M. de, ob. cit, cap. XIV, pp. 45-45V.

54 Ibidem, p. 43

55 Ibidem., pp. 40-41; RoA, M. de, Veneración y fruto de las sagradas imágenes i Reliquias. Historias $i$ exemplos a este propósito, Sevilla, 1626.

56 Sánchez de Feria y Morales, B: ob. cit., t. III, p. 43. Véase Nieto Cumplido, M: "La devoción a María en la Diócesis de Córdoba durante la Baja Edad Media", Actas Congreso sobre religiosidad popular en Andalucía, Cabra (1994) 
le dio vida para que le sirviese. Cuenta que cuando los moros tomaron la ciudad, los cristianos la escondieron entre los montes por no poder llevarla a otro sitio sin la conveniente reverencia. Tiempo después se le "apareció" en una cueva a un pastor humilde que estaba rezando mientras apacentaba a su ganado, y con su resplandor quedó asombrado. La Virgen le habló anunciándole su voluntad de ser "escudo y guarda de esta nobilísima villa", mandándolo a comunicar la revelación milagrosa a sus habitantes. Tras certificar el hecho, el cabildo eclesiástico, la gente, clérigos, cofradías y hermandades, regidores y jurados fueron en devota y solemne procesión a llevar la imagen a la Iglesia de Santa María. Pero las historias refieren que la Virgen quiso quedarse en lo alto de los montes "para que todos la vieran y a su grandeza se dirigieran pidiendo su intercesión y ruego", de modo que aquel lugar, rodeado y cercado de altas y fragosas peñas, que había sido albergue de fieras y animales se transformó con la sagrada imagen en "casa de paraíso" para sus fieles:

"De forma que lo que antes era fragoso y nido, agora es montes, y peñascos del cielo, después que la Reyna de Gracia, Madre de toda mansedumbre se dignó abaxar a ellos, desterrando de alli todo género de malezas, dexando llena la villa de bienes espirituales y divinos: y juntamente en sus vegas y campiñas, abundancia de frutos temporales...". ${ }^{57}$

Allí encontraron eficaces favores para librarlos de los peligros y calamidades del mundo:

“En sus manos los niños no mueren, los muertos resucitan, los leprosos, tullidos y mancos reciben entera salud, los tristes y afligidos consuelo, y los demás desta villa dan infinitas gracias a Dios en la alabanza desta Divina Patrona y Abogada por las mercedes que de su poderosa mano cada día reciben...siempre que en Carmona ay aflicciones, trabajos y necesidades, el cabildo Eclesiástico y Secular, acuden con gran devoción a su sagrado Templo, con procesiones, rogativas, para que en nombre desta celestial Señora, alcancen el remedio Della. ${ }^{25}$

En 1447, por iniciativa de los Reyes Católicos, la ermita se convirtió en monasterio y el arzobispo de Sevilla, don Pedro González de Mendoza, dio a los frailes Jerónimos observantes aquel lugar con todas las rentas y beneficios. Su templo edificado hacia 1554 se llenó de tumbas de caballeros y de exvotos que testimoniaban la devoción extendida por Marchena, Mairena, El Arahal, El Viso, Gandul y otras comarcas gracias a los milagros de la Virgen de Gracia recogidos en un libro escrito en lengua vulgar por los frailes. Asimismo otras pruebas autenticaron su verdadera sacralidad,

57 Baptista Arellano, J. S: Antigüedades y excelencias de la villa de Carmona y compendio histórico, Sevilla, 1626, pp. 282- 283v. Anónimo, Quaderno de noticias que pertenecen a la invención de Nuestra Señora de Gracia y a la ciudad de Carmona, Biblioteca Colombina, MS., Sevilla, 1602. Véase GonzÁLEZ JimÉnEZ, M: "Sobre los orígenes de la devoción de Nuestra Señora de Gracia, Patrona de Carmona", en Carmona Domínguez, José María (Dir), La Virgen de Gracia de Carmona, Hermandad de Nuestra Señora la Santísima Virgen de Gracia, Carmona, 1990 y Rodríguez Becerra, S: "La Virgen de Gracia de Carmona: relación entre patrona y comunidad", en Carmona Domínguez, José María (Dir), La Virgen de Gracia de Carmona, Hermandad de Nuestra Señora la Santísima Virgen de Gracia, Carmona, 1990

58 Baptista Arellano, J. S: ob. cit., cap. IX, p. 58v. 
como han sido las referencias a su origen antiguo y sobrenatural del que se dice que durante años ha estado la imagen bajo la tierra húmeda sin sufrir ningún daño, ni perdido el color del rostro, ni corrompido la madera de su cuerpo. Religiosos del convento de San Jerónimo certificaron que habían querido copiar la efigie y rostro pero los pintores cada vez que intentaban ponerlo en obra hallaban a la Virgen diferente. Los mismos testimonios dieron los vecinos de Carmona que llevaron al convento afamados artesanos pero no pudieron copiar ni reproducir ese modelo.

Merece también destacarse la aparición de la Virgen e inventio de su imagen ocurridos en el sitio de la Fuensanta, en Córdoba. Saliendo de esta ciudad por la puerta de Baeza, con dirección a las "deleitosas riberas del celebrado Betis" se llegaba a un sitio llano y apacible, de gran devoción al que los habitantes de la ciudad y su comarca asistían continuamente. El lugar, donde se alzaba un fuerte puente bajo el que se encontraba un arroyo que descendía de la Sierra Morena o "Montes Marianos" -al que llaman Las Peñas- era, según se escribe, un "sitio precioso donde la vista y el oído se recrean", con variedad de huertas, bellísimos narcisos, copiosos árboles y agua corriendo. Este "Paraíso terrenal" se convirtió en lugar de singular consuelo, en santuario donde se favorecían el alma y el cuerpo.$^{59} \mathrm{La}$ aparición de la Virgen Nuestra Señora, luego su "invención" (hallazgo de su imagen) y los milagros fueron las causas de que se operara esta transformación del lugar al que se denominó "Fuensanta", el sitio de mayor demostración de devoción, veneración y religiosidad de los cordobeses.

Sucedió la aparición y revelación en 1420, en el reinado de Juan II y en tiempos del Obispo de Córdoba, Sancho de Rojas. La tradición cuenta que a Gonzalo García, vecino de la Parroquia de San Lorenzo, cardador de lana, hombre virtuoso y devotísimo de la Virgen -afligido por la enfermedad de su mujer e hija- se le aparecieron cerca del arroyo de las Peñas dos mujeres hermosas y un mancebo: Nuestra Señora y los santos mártires patronos de la ciudad, Acisclo y Victoria, que le dijeron que bebiendo del agua tendría salud él y su familia. Desde ese momento, muchos fueron los milagros que obró la Virgen allí a través del agua. ${ }^{60}$

Con el tiempo, otro hecho reafirmó que este lugar era el "elegido por el cielo", fue con motivo del hallazgo de una imagen de la Virgen con el niño Jesús en brazos -que se cree era del tiempo del rey Recaredo- por un ermitaño. Creció la fama de este lugar con los "sucesos maravillosos", transformándose en uno de los principales receptáculos de abundantes limosnas del Cabildo de la Iglesia de Córdoba que ordenó edificar allí un pozo, un gran humilladero y luego una iglesia. ${ }^{61}$ La devoción y el culto a la sagrada imagen que creció con las noticias de sus milagros, determinó que el Cabildo viese la necesidad de un lugar "más decente y de mayor honor para la Virgen", que fue trasladada a la nueva iglesia, concurriendo toda la ciudad en procesión general

59 VACA de Alfaro, E: Historia de la aparición, revelación, invención y Milagros de la soberana imagen de Nuestra Señora de la Fuensanta que se venera en su devotísimo santuario extramuros de la ciudad de Córdoba, desde el año de 1420, Córdoba, 1795 (reimpresión), cap. I, pp. 3-5. y SÁnchez DE FERIA y MorAlES, B: Palestra Sagrada o memorial de santos de Córdoba con notas y reflexiones críticas sobre los principales sucesos de sus historias, t. III, Córdoba, 1772, pp. 11-23

60 Vaca de Alfaro, E: ob. cit. p. 8

${ }^{61}$ Ibidem., p. 25 
y con alegres demostraciones para su "santa patrona", que era "amparo, consuelo, refugio, gloria y honra de este suelo". ${ }^{2}$

Con los milagros de los siglos XVI y XVII recopilados por las historias eclesiásticas se muestra cómo se había extendido la devoción de numerosos fieles que acudían y visitaban a la Fuensanta, encomendándose a la Virgen, pero también cómo se promovía la veneración a Nuestra Señora. Los favorecidos con las acciones bienhechoras y con la protección mariana fueron cordobeses, vecinos de la ciudad, cristianos, judeo-conversos, enfermos, personas en peligro, mujeres, hombres, niños y clérigos. El agua milagrosa de la Fuensanta se convirtió para los creyentes cristianos en "dadora de vida", "fertilizadora de la tierra", "renovadora y regeneradora espiritual y corporal" así lo demuestran gran número de testimonios recogidos que exaltan los prodigios de la Virgen y la fama del lugar.

Gracias a los trabajos salidos de la pluma de Enrique Vaca de Alfaro tenemos noticias sobre esta imagen que goza de la condición de aparecida. Publicó un importante estudio histórico sobre la Virgen cuyos contenidos fueron ampliados por otros historiadores. Registró numerosos milagros concedidos: a un vecino de Córdoba enfermo; a una mujer judeo-conversa tullida que pidió a sus hermanos que la llevaran a la Fuensanta y aunque se dice que no tenían fe, la echaron al agua comprobando que se curaba. Anotó que en 1548 Hernando de Molina, de la ciudad de Córdoba, fue apresado en Tolosa (Francia) por los enemigos, se encomendó a la Virgen que se le apareció y lo puso a salvo; hizo referencia a Juan del Monte que volviendo de las Canarias lo sorprendió la tormenta y se encomendó a la Virgen que sosegó el mar; a lo ocurrido en 1554 con el hijo de unos vecinos de Córdoba que se cayó al pozo del humilladero y a la vista de todos el agua rebozó, preguntaron al niño por lo sucedido y confesó que había visto a la Virgen y lo había salvado Nuestra Señora. Recogió también el testimonio de un vecino que en 1571 peleó en la guerra de Granada de las Alpujarras y al ser herido se encomendó a la Virgen que lo curó, el milagro ocurrido en 1588 con una mujer que habiendo perdido el habla se curó y el de un jurado de la ciudad que estaba desahuciado y sanó. El autor mostró que la Virgen había resucitado muertos, dado la vista a los ciegos, sanado a paralíticos, hidrópicos, cojos, mancos y a los que padecían de otras graves y peligrosas enfermedades, había liberado a hombres y mujeres y en necesidades de agua, hallaron con su intercesión abundante pluvia. Por todo ello escribió: "es muy numeroso el concurso de toda Andalucía y la mayor devoción de Córdoba. Príncipes, señores de toda la región envían a Nuestra Señora riquisimos presentes y alhajas costosísimas. " 63

Considerada así "consuelo de la ciudad y su diócesis", la devoción a esta Virgen trascendió el reino de Córdoba, llegó a toda Andalucía, a España y a su Imperio, porque desde las Indias se remitieron limosnas a la Fuensanta.$^{64}$ De este modo ese espacio sacralizado con la aparición de la Virgen, el hallazgo de su imagen y sus milagros, convirtió a la tierra de Córdoba en un eje del culto mariano, la fama del santuario y del Cabildo de la Iglesia que tenía el patronato había sido tanta que de muy distintas tierras y regiones acudía gente a pedirle favores y en ella lo hallaban. Gracias a la

\footnotetext{
62 Sánchez de Feria y Morales, B: ob. cit., t. III, p. 23

${ }^{63}$ Vaca de Alfaro, Enrique, ob. cit., cap. III, pp. 38-89 y pp. 90-91

${ }^{64}$ Ibidem., cap. III, pp. 38-89
} 
Virgen no había dolencia incurable, todos acudían a la Fuente "como a piscina", y los enfermos con admirables efectos con aquellas aguas quedaban curados: ${ }^{65}$ Córdoba era la gran privilegiada, tenía

"por dádiva del cielo una Fuente que con sus aguas la riegan, una fuente que la fertiliza, la Imagen de Ma. Santísima de la Fuensanta, de donde se derivan todas sus dichas, con su misericordia tiene asegurado su patrocinio."

El culto a la Virgen de la Cabeza también ha recibido gran difusión a través de las historias. Narran que su culto y devoción renació cuando un pastor de Colmera (Granada) encontró su imagen en 1227 en Sierra Morena, término municipal de la ciudad de Andújar. Tras sucederse por varias noches grandes luces, continuos resplandores y el sonido de campanas que repicaban, se sintió atraído por el lugar de donde procedían y al llegar a la cima de un cerro vio a la Virgen que le ordenó anoticiar de aquella aparición prodigiosa a la ciudad, a los dos cabildos secular y eclesiástico, a fin de que se edificase en ese sitio más alto y empinado un templo donde los pobladores hallarían "remedio en todas sus necesidades y trabajos". ${ }^{66}$

Para que no dudaran de dar crédito al hecho, la Virgen curó milagrosamente la mano del pastor que era manco, y una vez que la iglesia y los regidores de Andújar certificaron sus dichos, caminaron hasta aquel sitio en solemne procesión para buscar la imagen. Como un capitán o un "nuevo Colón" el pastor guió a numerosos devotos entre las motas y el espeso monte donde había descubierto aquel "tesoro", allí una nueva señal los convenció de la sacralidad de la preciosa "reliquia", al encontrar la imagen mariana cercada de resplandecientes luces. Los sacerdotes

"aviendo reconocido el color, el pelo, lo maciso, la dureza y el olor de la madera, unos y otros vinieron a conocer como era de cedro y que no se habia hecho en estas Provincias la Sagrada Imagen, con que se persuadieron que era don enviado del cielo o alguna reliquia grande que escondieron los christianos quando se perdió España y que sin duda avía estado con muchos honores en Andújar, pues al tiempo que faltó la fe y el culto divino en ella, le pusieron campana en sitio tan fragoso y retirado, en el qual no se podía aver puesto de quinientos años a aquella parte, por aver estado toda esta comarca ocupada de moros y porque los vestidos y moho de la campana denotaba grandísima antigüedad". ${ }^{67}$

Tomándola por abogada e intercesora, por patrona y defensora, los pobladores prometieron cumplir lo encomendado, y para servirla con devoción y veneración hasta que se fabricase el templo, la trasladaron a la ciudad en hombros. Con

${ }^{65}$ SÁnchez de Feria y Morales, B: ob. cit., t. III, p. 11,

${ }^{66}$ Gómez Martínez, E: "La devoción popular a Nuestra Señora de la Cabeza de Sierra Morena en la Andalucía de los siglos XVI y XVII", en La religiosidad popular II. Vida y muerte: la imaginación religiosa, Anthropos, 2003 ( $2^{\circ}$ ed); Cea Gutiérrez, A. y Torres Martínez, J. C: "Retratos de un santuario. El pulso devocional de Nuestra Señora de la Cabeza en Andújar a través de un manuscrito inédito del siglo XVI", en Religión y Cultura, vol 2 (1999)

${ }^{67}$ Ibidem., p. 227 
"extraordinario contento y regocijo" fue recibida en Andújar con la mayor fiesta y solemnidad que pudieron, depositando la imagen en la Iglesia de Santa María. Luego, la imagen volvió al cerro de la Cabeza donde se le construyó una ermita en 1287. Manuel Salcedo Olid ofrece una interpretación sobre algunos aspectos simbólicos del nombre de la Virgen y el sitio de la inventio:

"Cabeza es preferida a cualquiera de los demás miembros del cuerpo, su nombre designa algo superior, en él están cifradas las mayores prerrogativas y excelencias de la Virgen por ser Cabeza, Reina y Señora de todas la criaturas, como Madre de aquel que es Cabeza de todo y quiso que se le fabricase la casa en aquel monte para que sus intercesiones estuviesen más potentes y que entendiesen que no se estrechaban sus beneficios a los límites de una ciudad sola, sino que toda España, ricos y pobres, grandes y pequeños pudieran acudir". ${ }^{68}$

La gran devoción que concitó esta imagen llevó a la ciudad a trasladar su fiesta a un domingo de abril "por ser tiempo más templado y más acomodado para dar posada y proveer de mantenimientos a los peregrinos." Al decretar 8 días de ferias francas pudieron acudir tantos mercaderes de platería y otras mercaderías que aquel desierto se transformó con tanta abundancia en un sitio donde "todo sobraba y nada faltaba". Juan de Ledesma alabó la organización de la fiesta bajo la dirección de 12 caballeros de las familias más nobles, un prioste y dos alcaldes de la ciudad, las ofrendas que hacían sus devotos en joyas y vestidos preciosísimos, andas de plata muy ricas y costosas donde la llevaban en procesión, gran número de lámparas y muchas rentas para comprar aceite y mantenerlas encendidas. ${ }^{69}$

Antonio Terrones de Robres escribió al respecto:

"Todos los cofrades acudieron a la iglesia en las vísperas de la fiesta, con sus pendones, estandartes y banderas acompañados de muchas danzas y música de ministriles, todos diestros en su arte...es tanta la confusión en la iglesia que apenas conocen los cofrades sus lugares y antigüedades que por no perderlas suelen tener alborotos y disensiones, las cuales con facilidad se remedian y quietan con la autoridad de los diputados de la cofradía de Andújar, que todos son conocidos y respetados, por andar como andan en cuerpo con sus bastones en las manos y bandas rojas en el pecho gobernando la fiesta y procesión. Otro día domingo habiendo hecho cada cofradía una solemne fiesta en el altar de la Virgen, se dice la misa mayor con mucha solemnidad. Los capellanes ponen la santa imagen en las andas de plata y la entregan a la cofradía de Andújar que la llevan hasta la puerta de la iglesia y alli la entregan a la cofradía de Arjona y así la van recibiendo las demás". ${ }^{70}$

Así pues, el ritual siguió un orden bien dispuesto que marcaba la primacía de la cofradía de Andújar que obtuvo bulas papales que imposibilitaban la intromisión del clero y el obispo de Jaén en el santuario y su fiesta y en cuyo término se halló

\footnotetext{
${ }^{68}$ Salcedo Olid, M: ob. cit., pp. 231-232

69 Ledesma, J. de: ob. cit., p. 69

70 Terrones de Robres, A: ob. cit., p. 180
} 
la imagen, luego la de Arjona, lugar donde residía el pastor que la encontró, y la de Colomera, que era lugar de su nacimiento. ${ }^{71}$

En la procesión la gente esperaba verla y tocarla para pedirle sus favores y recibir su gracia, de ahí que el citado autor haya expuesto:

“... alli van clamando y dando gritos los ciegos, mancos y tullidos, pidiendo sanidad a la Virgen; allí los padres llenos de fe y devoción con lágrimas y sollozos arrojan a sus hijos mudos y ciegos a los pies de la Virgen... no son bastantes los capellanes ni diputados a desasir de las andas a los muchachos y a los padres, muchos de los cuales quedan sanos, obrando Nuestro Señor a vista de todos milagros, por eso la devoción de esta santa casa ha crecido tanto y aumenta cada día, de cuyos despojos, vestidos y militas, grillos y cadenas de cautivos que esta milagrosa Virgen ha librado están llenas las paredes de esta iglesia con muchos lienzos de pintura donde están los milagros con los nombres de las personas con quien los ha obrado y de donde son vecinos y naturales". ${ }^{72}$

\section{CONSIDERACIONES FINALES}

Lo que en la actualidad llamamos "arte religioso", en la Edad Media quedó subordinado como ritual de significación a la relación individual y colectiva con lo sagrado. En el pasado, ciertas imágenes marianas (esculturas, tallas y pinturas) fueron concebidas para un marco devocional, como manifestaciones visibles de la Madre de Dios y, en consecuencia, merecieron un culto y un trato especial al funcionar como intermediarias entre los fieles y la divinidad. Aunque reconocidas como objetos o instrumentos que ayudaron a promover, inducir, canalizar y fortalecer las experiencias religiosas de las sociedades, esas funciones conocieron épocas de esplendor y de crisis, motivo por el cual la Iglesia Católica elaboró una teoría de las imágenes, se dotó de un corpus teológico y llevó adelante un mayor control de las prácticas eligiosas vinculadas a éstas, a fin de legitimarlas y enfrentar las controversias.

Las polémicas planteadas con las imágenes de culto giraron en torno al problema de la relación entre significante (objeto) y significado (prototipo), entre realidad y semejanza, a la coexistencia o dominio de imagen y texto; la justificación del poder y la sacralidad de las imágenes, a la necesidad de distinguir adoración de veneración que transitaba hacia el prototipo. Tales cuestiones pusieron en juego la pureza de la fe, la verdadera espiritualidad de las prácticas religiosas, la pérdida del poder de la institución eclesiástica que se hallaba vinculada a las imágenes y el uso de éstas como medios de educación religiosa de los fieles.

En lo que respecta al proceso de aceptación de la sacralización de las imágenes en España también se produjeron -como en otras partes de Europa- reticencias. Es po-

${ }^{71}$ En Jaén la imagen se veneraba en una ermita llamada de Belén o San Nicasio, sita extramuros, pero luego se trasladó a Las Peñas de Nuestra Señora y con el establecimiento de los Padres Capuchinos en 1624 se levantó un convento cuya capilla principal se consagró a la Virgen de la Cabeza. Véase Patrona de la Diócesis (Boletín informativo de la Real Cofradia de la Santísima Virgen de la Cabeza de Jaén), N 1, Fiestas de romería, 1991

72 Terrones de Robres, A: ob. cit., cap. XVI, pp. 180v-181v. 
sible que las leyendas medievales además de incitar a la devoción y de instruir a los fieles, resultaran imprescindibles por su valor edificante para aquellos grupos (moros, judíos y herejes) que ponían a las imágenes en entredicho y para enfrentar acusaciones de idolatría o dudas de antigua raigambre. Consideramos que las leyendas que circularon a lo largo de la Edad Media se fueron enriqueciendo en otras obras que se difundieron rápidamente a través de la imprenta, en los siglos XVI y XVII, en esa larga tradición exaltaron el carácter sobrenatural y maravilloso de las imágenes en el marco de la promoción de la figura de María, en las doctrinas del Concilio de Trento. Sensible a las críticas, los teólogos católicos que se enfrentaron con los reformistas, intentaron mostrar la diferencia doctrinal que los separaba de los protestantes y buscaron legitimar el culto a las imágenes milagrosas a modo de reliquias.

Las obras aquí tratadas demostraron que desde el siglo XIII se potenciaron las advocaciones marianas, especialmente durante la Reconquista se valoró a la Virgen como protectora, salvadora y liberadora, como principal artífice de la victoria cristiana, de la restauración y revitalización del cristianismo en la región andaluza, tras varios siglos de presencia musulmana. Por su intercesión y milagros, sus imágenes sagradas constituyeron un pilar fundamental en la profesión de fe de los cristianos y dieron lugar a una larga tradición en la veneración y culto de quien los andaluces habían recibido infinidad de bienes y beneficios, consuelo, socorro y remedio en todo momento, razón por la cual las devociones marianas alentaron unas prácticas religiosas basadas en oraciones, invocaciones, ofrendas o exvotos (en agradecimiento o recuerdo por haberles concedido un don), limosnas, procesiones, rogativas, fiestas y fundaciones de cofradías, monasterios, conventos, así como la construcción en su honor de ermitas y santuarios. Incluso la búsqueda de protección de la Virgen tuvo en el interior de los templos efecto sobre las costumbres funerarias -como lo había tenido la búsqueda de proximidad a las reliquias corporales de los santos- pues incitó a los reyes y a los linajes más importantes de las ciudades no sólo a encomendar su alma, sino a vincular su cuerpo a las imágenes marianas, haciendo que los lugares de enterramiento se precisaran en los testamentos, con la elección de la capilla y ante la imagen sagrada, asociando así el prestigio familiar a su espacio de culto. Como se ha advertido en estas páginas, la piedad popular y las sensibilidades religiosas se expresaron y apoyaron en manifestaciones externas, rituales y ceremonias.

Por ello resulta esencial prestar atención a la relación entre la tradición oral sobre los milagros de la Virgen a través de sus imágenes y su posterior difusión en la narración escrita, porque en ésta última el discurso erudito y eclesiástico plasmó la experiencia religiosa andaluza, dotó a la leyenda de una funcionalidad, incorporó una teoría de la imagen y justificó su culto a través de un relato historicista legitimador de la importancia de los santuarios. Así pues, la mayoría de los relatos hagiográficos e historiográficos sobre antiguas imágenes marianas veneradas, donadas, "aparecidas" o halladas en Andalucía fueron especialmente sensibles a las polémicas iconoclastas en la cultura cristiana, y en ese sentido, supieron responderlas convenientemente para dar un significado profundo a las imágenes. Precisamente, a partir del siglo XII el desarrollo del culto mariano redundó no sólo en la proliferación de sermones y predicaciones, de hagiografías y de una literatura de milagros producidos por las "apariciones" y "visiones" de la Virgen, sino también a través de su corporeización en 
imágenes para extender las devociones. Los ejemplos documentados en las leyendas andaluzas dejan bien claro que el proceso de sacralización de las imágenes se apoyó en una serie de fundamentos teóricos.

El milagro fue la demostración más patente de autenticidad del carácter sagrado de las imágenes religiosas, avaló la teoría del transitus que propugnaba el poder o virtus del representado en la imagen. Los casos a los que se ha hecho referencia expresan bien el vínculo entre la representación (la imagen) y el representado (la Virgen) demostraron la conexión de lo espiritual con lo material (íconos o imágenes tridimensionales) transformando a las imágenes marianas en reliquias, haciendo válida la mediación entre el fiel y el personaje sagrado. Así la iconodulía mariana validó tanto la "aparición" de la Virgen como su "presencia".

Algunas de las leyendas citadas proclamaron la excepcionalidad de la naturaleza de las imágenes marianas milagrosas, identificándolas con la mayor reliquia conocida de la época de los apóstoles que reunía una gracia especial, la realizada según la tradición por el evangelista San Lucas, de esta manera las imágenes escultóricas que por su tridimensionalidad podían prestarse mejor a las semejanzas con la figura histórica de la Virgen, copiaron el carácter de aquél antiguo y sagrado ícono. Ahora bien, ninguna obra registró la más mínima controversia que cabía esperarse de una imagen que poseía una existencia única, pero que se había multiplicado circulando por la cristiandad europea. Ecija con su Virgen del Valle y Andújar con su Virgen de la Cabeza, por ejemplo, reivindicaron la autenticidad histórica y la posesión de la imagen que era reproducción fidedigna de la Virgen.

En otros casos, las imágenes se vincularon con uno de los siete varones apostólicos que evangelizaron España: por ejemplo la Virgen de la Cabeza con San Eufrasio, o a uno de los primeros obispos de Andalucía como La Virgen del Valle con San Leandro y San Fulgencio. O bien postularon que el origen de la imagen databa de época visigoda, así las que se habían venerado desde antes de la invasión musulmana sirvieron de argumento para el recuerdo de su pasado cristiano, para justificar el culto desde los primeros tiempos de la Iglesia. En ese sentido, el relato de la translatio e inventio fue inseparable de la legitimación de la Reconquista garantizada por medio de la intervención mariana, a través de sus imágenes milagrosas que, reencontradas o descubiertas, avalaban el derecho sobre los territorios cristianos otrora perdidos, como sucedió con las leyendas de la Virgen de la Coronada, la Virgen de la Peña y la Virgen de los Mártires de Jaén; Nuestra Señora del Rosario, Nuestra Señora del Alcázar de Baeza; Nuestra Señora de Sevilla y La Virgen de Gracia de Carmona.

Otro principio fundamental en el que se basaron las leyendas andaluzas fue el de la acheiropoiesis, es decir la realización de imágenes por mano no humana. El silencio absoluto o muy pocas referencias sobre su valor material, la falta de datos acerca de la creación de pinturas o esculturas en talleres y el desconocimiento de los artistas aludían a su génesis sobrenatural y origen celestial, afirmándose así concientemente su autonomía respecto a las personas. Ejemplos de este tipo se encuentran en una de las versiones legendarias de la Virgen de los Reyes y la Virgen de la Antigua de Sevilla. Cualquier intervención artística hubiera desvirtuado el principio de la sacralidad como así también toda referencia a su adquisición por compra. 
Por otra parte, la conservación de la imagen intacta en el tiempo, sin daño ni alteración, la no admisión de su destrucción o sustitución de la imagen por otra en los altares, o los impedimentos para reproducirla o copiarla fueron también recursos hagiográficos que sirvieron para afirmar la "presencia" intemporal de la Virgen, para ofrecer una prueba doble de antigüedad y pervivencia, como ha quedado reflejado en las historias de la Virgen de la Antigua, la Virgen del Valle, la Virgen de la Coronada y la Virgen de Gracia.

Igualmente decisivo fue que los relatos remarcaran incluso la reproducción de la figura de María de manera exacta y fidedigna a los modelos originales que se habían hecho "presentes" en "apariciones" y "visiones", porque las separaba de las obras comunes. Tal identificación entre la apariencia física de la Virgen "aparecida" y la efigie escultórica respaldó la legitimidad de la imagen, como se cree que ocurrió con la Virgen de los Reyes, la Virgen de Gracia y Nuestra Señora de la Fuensanta.

Ninguno de estos temas fue superfluo. Las leyendas incorporaron una cuidadosa selección de elementos que fueron requisitos fundamentales para presentar la sacralidad de las imágenes. Se admitía con todo ello el valor de la imaginería como medio de adoctrinamiento, como objeto de culto, como vehículo de enseñanza y devoción y como arma en los debates. La historicidad y la experiencia religiosa subrayaban el aura de lo sagrado sobre lo artístico y descansaron en tres hechos fundamentales: los prodigios y señales para indicar los lugares donde se hallaban las imágenes, las acciones atribuidas como hablar, aparecer y trasladarse y los milagros que ratificaban la intercesión divina. Todos se pusieron al servicio de la propaganda de la fe y el culto.

El testimonio de milagros procedente de gentes sencillas (hombres, mujeres y niños) o de monjes, clérigos y obispos representaba el punto de vista popular y docto que concebía a las imágenes marianas como reliquias. Que los testigos de milagros y los descubridores "elegidos" hayan manifestado tales creencias ilustra la emergencia activa de una religiosidad fuertemente arraigada en el culto mariano que interpreta que las imágenes adquirían el status de símbolos sagrados si habían sido dispuestas por Dios, si habían estado en contacto con cuerpos o restos de santos, o fueron pintadas por ellos, o efectuaron milagros. Las leyendas tocaban así un asunto delicado si se tiene en cuenta que en ningún caso se hablaba de la necesaria consagración eclesiástica que garantizase la calidad de imágenes sagradas, no era esta institución religiosa la que confería ese poder o atributo. La sacralidad se daba sin su intervención, los sacerdotes no eran autores o creadores de esa condición, allí radicaba el mérito de las leyendas sobre imaginería religiosa.

Sin embargo, la relación entre la religiosidad oficial y la popular -o sus tensionesse puso de manifiesto al intentar la Iglesia controlar las tendencias hacia el "maravillosismo" y los prodigios, depurar creencias y disciplinar ciertas prácticas, rituales y el uso de las imágenes a fin de eliminar elementos que ensombrecían el culto. Para ello dictó normas para la declaración de milagros y "apariciones" que requerían la intervención de los cabildos catedralicios, la aprobación del obispo, las declaraciones de testigos, los informes notariales para dar en la documentación de los hechos recopilados cuidadosas explicaciones, exámen y certificación de la autenticidad de los mismos, con el fin de restaurar la confianza y hacerlos indiscutibles. De este modo la defensa de las imágenes y el culto implicó también su control, por un lado se regla- 
mentó el uso de las imágenes en las procesiones, por otro se fijaron ciertas pautas para la iconografía sacra y las esculturas para darle mayor formalismo. ${ }^{73}$

Las tradiciones aquí citadas repiten casi un mismo esquema: las imágenes marianas custodiaron y protegieron a las ciudades y a sus habitantes, pero no deja de ser significativo que en el transcurso de los siglos se hayan producido numerosos casos de inventio en montes, cuevas, dehesas, ejidos, parajes descampados que completaron la sacralización de los términos municipales. En esos lugares, "elegidos" la "presencia" de la Virgen actuó como fertilizadora y fuente de vida transformando el paisaje natural en lugar sagrado, con la creación de santuarios y la fundación de conventos y monasterios que, entre los itinerarios de la fe, fueron meta para los cristianos que marcharon hacia ellos como si fueran a la "Tierra Prometida".

Los "hechos maravillosos" producidos en los espacios rurales andaluces rompieron con el largo predominio urbano fundado en la concentración de reliquias santas, operadas a veces por medio de la práctica de la translatio desde extramuros hacia los centros religiosos localizados en el interior de las ciudades. De esta manera, después de la Reconquista del siglo XIII, otro de los símbolos religiosos, las imágenes marianas, colonizó el espacio natural que estaba en la frontera o límites parroquiales y municipales, revalorizándolos. La invasión musulmana había privado a Andalucía de sus auxiliadores divinos, los santos, cuyas reliquias fueron trasladadas a lugares más seguros, quedándose allí hasta que concluyó el conflicto étnico-religioso entre cristianos y moros. Ese vacío creó la necesidad por parte de la Iglesia de cubrirlo con otra "presencia sagrada universal", así fue que los santuarios de la Virgen María ganaron preeminencia. ${ }^{74} \mathrm{Si}$ bien muchas imágenes marianas "viajaron" y fueron trasladadas para salvaguardarlas de la destrucción musulmana, otras se quedaron, fueron escondidas, guardadas, enterradas, de manera que esa "pobreza" de reliquias santas quedó compensada con una intercesora no especializada, madre de toda la comunidad, a la que recurrían todos los devotos. ${ }^{75}$

${ }^{73}$ Los concilios provinciales y las constituciones sinodiales recordaron a los fieles que debían poner sus ojos no en el valor de la hechura y su ornato, sino en lo que las imágenes representaban para mover a una devoción auténtica, debían adaptarse a la historia sagrada y hagiográfica, guardar un estricto decoro moral, preferentemente debían ser de cincel y de bulto y las esculturas de vestir debían estar honestas y decentemente ataviadas. Se confió a los obispos y a través de ellos en los vicarios y visitadores pastorales el cumplimiento de normas referidas a las imágenes para señalar los lugares para exhibirlas, donde se les rendiría culto, cuándo sacarlas en las procesiones y especialmente se dirigieron a las cofradías para que las tuvieran con honor y decencia requerida. Véase Constituciones sinodiales hechas y ordenadas por Alonso de Fuente el Sauce, obispo de Jaén (1511): las celebradas en la catedral de Córdoba el 23 de junio de 1566 analizadas por HerRerA Mesa, P. P: "Decretos sobre imágenes en las constituciones sinodiales del obispo Rojas y Sandoval", Alto Guadalquivir (1991); Rodríguez BeCERRA, S: "La religión de los andaluces" en Eduardo Moyano Estrada y Pérez Yruela, Manuel (coors), La sociedad andaluza, Instituto de Estudios Sociales de Andalucía (IESACSIC), Córdoba, 2002

${ }^{74}$ WiLliam, C: "De los santos a María, patrona de las devociones en santuarios españoles desde el principio de la Edad Media hasta nuestros días”, Temas de Antropología Española, Akal, Madrid, 1976 y Apariciones en Castilla y Cataluña (s.XIV-XVI), Madrid, 1990

75 Velasco Maillo, H: "Imágenes y santuarios: una aproximación desde los relieves y sombras de los relatos histórico-legendarios", en Rodríguez Becerra, Salvador (Coord) Religión y cultura, vol II (1999); Alvarez Santaló, C: "La escenografía del milagro hagiográfico y la construcción del milagro colectivo", en Rodríguez Becerra (coord), Religión y cultura ...; Rodríguez BeCERRA, S: "Santuarios y milagros en la religiosidad de Andalucía", Demófilo 16, (1999). 
Ahora bien, la santidad de las imágenes y sus milagros también quedaron asociados a las iglesias y especialmente a ciertos modelos monásticos, muchos de los cuales habían vuelto a la observancia de la regla o se fundaron por las devociones marianas, o según las leyendas por la voluntad divina. De este modo, en la mentalidad o imaginario colectivo el espacio litúrgico y los claustros fueron lugares "elegidos" para los milagros, manifestándose así no sólo la grandeza espiritual de las ordenes religiosas que custodiaban las sagradas imágenes, sino su capacidad de capitalizar los mecenazgos, los privilegios reales, las bulas papales, así como unos ingresos económicos regulares con beneficios, donaciones y limosnas provenientes de los devotos, como sucedió con los conventos y monasterios puestos bajo la dirección de Jerónimos, Dominicos, Agustinos y Mercedarios.

En todos los casos reseñados, las imágenes sagradas despertaron un profundo sentido de la identidad colectiva. Las leyendas reafirmaron el vínculo establecido entre la imagen, el representado, la comunidad y el lugar del milagro. La conciencia de esa vinculación con el símbolo religioso se remarcó acentuando la apropiación, llamándola "Nuestra", o confiriendo un nombre definido por la topografía cuando no se basó en una apariencia especial que la hacía identificable como santo local, distinguiéndola de las advocaciones marianas de otros lugares. La resistencia de la Virgen a ser trasladada constituyó un hecho significativo para reafirmar que la imagen era susceptible de convertirse en patrimonio de las comunidades, pero también las fiestas (con su mezcla lúdica y religiosa) y las procesiones, como actividades comunitarias, fueron vehículos de suma importancia para la enseñanza catequística y propagandística que permitían visualizar el dogma y exaltarlo. En ellas las cofradías sirvieron de cauce de la religiosidad mariana, la misma retórica de las historias ilustraron también su riqueza y poder, y a menudo sus competencias. ${ }^{76}$

En suma, en el transcurso de la Baja Edad Media a la Edad Moderna los testimonios orales se fueron actualizando y reeleborando al ser transcriptos por laicos o religiosos que los reinterpretaron según los dogmas establecidos y difundieron los principales hechos de la historia religiosa hasta entonces dispersos, a fin de publicitar ante un círculo cada vez más amplio de lectores la eficacia de las imágenes marianas receptivas a las invocaciones, las oraciones, los sacrificios y peregrinaciones, su valor mediador y la justificación como objeto de culto. Las leyendas destacaron todos los estereotipos de las imágenes como Madre Universal y misericordiosa, los atributos como Reina de los cielos que fortalecían la idea de la Virgen como puente hacia Dios, como gran intercesora, como Señora del Mundo. Tales narraciones -que constituyen

76 Velasco Maillo, H: "La apropiación de los símbolos sagrados. Historias y leyendas de imágenes y santuarios (s. XV-XVIII)", Revista de Antropología Social, vol 5 (1996) y "Las leyendas de hallazgos y de apariciones de imágenes. Un replanteamiento de la religiosidad popular como religiosidad local", en Alvarez Santaló, Carlos, Buxó, María Jesús y Rodríguez Becerra, Salvador (coords), La religiosidad popular t. II, Vida y muerte, Anthropos, Fundación Machado, Barcelona (1989); Fernández SuArez, R: “Geografía religiosa y ermitas: la focalización de los símbolos sagrados”, en Religión y Cultura vol II...; RodRíGUEz BECERRA, S y Gómez Martínez, E (coords): "Santuarios andaluces", Demófilo 16 y 17, Fundación Machado (1995); Moreno Navarro, I: "Niveles de significación de los íconos religiosos y rituales de reproducción de identidad en Andalucía”, en P. Córdoba y J. P. Étienvre (coords.) Coloquio Internacional La fiesta, la ceremonia, el rito. Granada. Universidad de Granada (1990), pp. 91-104; DíAz TABEADA, J. M: "La significación de los santuarios" en La religiosidad popular: hermandades, romerías y santuarios vol III, (2003) 
un género literario bien definido de escritura religiosa- fueron producto o reflejo de la religiosidad popular y de la ideología de la Iglesia que encauzó y controló creencias y prácticas religiosas. Por la vía teológica el razonamiento estuvo encaminado a demostrar el paso de lo visible a lo invisible, de lo sensible al espíritu, el contacto entre el cielo y la tierra. Por la vía de los milagros a demostrar a los lectores la "presencia" de la Virgen en sus comunidades, de lo sagrado en sus vidas y de lo "maravilloso" en lo cotidiano, y a acentuar la íntima relación con su imagen y los centros cultuales donde estaban depositadas. Si bien su poder podía operar a distancia, los textos supusieron un medio de promoción devocional conservando la fama de los templos y santuarios. 